\title{
Brittle grain-size reduction of feldspar, phase mixing and strain localization in granitoids at mid-crustal conditions (Pernambuco shear zone, NE Brazil)
}

\author{
Gustavo Viegas ${ }^{1,2}$, Luca Menegon ${ }^{1}$, and Carlos Archanjo ${ }^{2}$ \\ ${ }^{1}$ School of Geography, Earth and Environmental Sciences, Plymouth University, Drake Circus, Plymouth, UK \\ ${ }^{2}$ Instituto de Geociências, Universidade de São Paulo, Rua do Lago 562, Sao Paulo, Brazil
}

Correspondence to: Gustavo Viegas (gustavo.viegas@plymouth.ac.uk)

Received: 14 September 2015 - Published in Solid Earth Discuss.: 30 October 2015

Revised: 15 February 2016 - Accepted: 23 February 2016 - Published: 9 March 2016

\begin{abstract}
The Pernambuco shear zone (northeastern Brazil) is a large-scale strike-slip fault that, in its eastern segment, deforms granitoids at mid-crustal conditions. Initially coarsegrained $(>50 \mu \mathrm{m})$ feldspar porphyroclasts are intensively fractured and reduced to an ultrafine-grained mixture consisting of plagioclase and K-feldspar grains $(<15 \mu \mathrm{m})$ localized in C' shear bands. Detailed microstructural observations and electron backscatter diffraction (EBSD) analysis do not show evidence of intracrystalline plasticity in feldspar porphyroclasts and/or fluid-assisted replacement reactions. Quartz occurs either as thick $(\sim 1-2 \mathrm{~mm})$ monomineralic veins transposed along the shear zone foliation or as thin ribbons $(\leq 25 \mu \mathrm{m}$ width $)$ dispersed in the feldspathic mixture. The microstructure and $c$ axis crystallographicpreferred orientation are similar in the thick monomineralic veins and in the thin ribbons, and they suggest dominant subgrain rotation recrystallization and activity of prism $\langle a\rangle$ and rhomb $\langle a\rangle$ slip systems. However, the grain size in monophase recrystallized domains decreases when moving from the quartz monomineralic veins to the thin ribbons embedded in the feldspathic C' bands $(14 \mu \mathrm{m}$ vs. $5 \mu \mathrm{m}$ respectively). The fine-grained feldspar mixture has a weak crystallographic-preferred orientation interpreted as the result of shear zone parallel-oriented growth during diffusion creep, as well as the same composition as the fractured porphyroclasts, suggesting that it generated by mechanical fragmentation of rigid porphyroclasts with a negligible role of chemical disequilibrium. Once C' shear bands were generated and underwent viscous deformation at constant stress conditions, the polyphase feldspathic aggregate would have deformed at a strain rate 1 order of magnitude faster than
\end{abstract}

the monophase quartz monomineralic veins, as evidenced by applying experimentally and theoretically calibrated flow laws for dislocation creep in quartz and diffusion creep in feldspar. Overall, our data set indicates that feldspar underwent a brittle-viscous transition while quartz was deforming via crystal plasticity. The resulting rock microstructure consists of a two-phase rheological mixture (fine-grained feldspars and recrystallized quartz) in which the polyphase feldspathic material localized much of the strain. Extensive grain-size reduction and weakening of feldspars is attained in the East Pernambuco mylonites mainly via fracturing which would trigger a switch to diffusion creep and strain localization without a prominent role of metamorphic reactions.

\section{Introduction}

Strain localization in shear zones is a fundamental process controlling deformation at plate boundaries and strength evolution of the lithosphere. The development of localized highstrain zones requires some form of strain weakening as the deformation progresses. Many studies have highlighted the important role of progressive grain-size reduction in promoting weakening and strain localization in the lithosphere (Warren and Hirth, 2006; Herwegh et al., 2011; Kilian et al., 2011; Bercovici and Ricard, 2012; Montesi, 2013; Platt, 2015). Intense grain-size reduction can lead to the activation of grainsize-sensitive creep as the dominant deformation mechanism, with a consequent potential increase in strain rate of up to 2 orders of magnitude in localized high-strain zones (War- 
ren and Hirth, 2006; Platt, 2015). Thus, investigating grainsize reduction mechanisms and microstructural modifications during development of shear zones is of paramount importance for our understanding of lithosphere deformation.

Rheological models of the middle continental crust are typically based on the extrapolation of experimentally derived flow laws of quartz and feldspars (e.g. Tullis, 2002; Okudaira and Shigematsu, 2012), so that shear zones in granitoids have often been used as natural laboratories to investigate strain localization in the middle crust and the associated microstructural modifications experienced by quartz and feldspars (Behrmann and Mainprice, 1987; Fitz Gerald and Stünitz, 1993; Fliervoet et al., 1997; Ingles et al., 1999; Tullis, 2002; Pennacchioni and Mancktelow, 2007; Menegon and Pennacchioni, 2010; Oliot et al., 2010; Kilian et al., 2011; Sullivan et al., 2013; Czaplinska et al., 2015). At pressure-temperature conditions typical of the middle crust, quartz is expected to be mechanically weaker than feldspars when deformation is accommodated by crystalline plasticity (Tullis, 2002, and references therein). Dislocation creep in quartz results in the formation of interconnected weak layers that accommodate most of the deformation, while feldspar deforms via fracturing (e.g. Handy et al., 2007). However, this static model does not consider the strain-dependent grain-size reduction and microstructural evolution of feldspars during shear zone formation. Even though in granitoids feldspar is commonly the strongest phase, feldspar-derived ultrafine-grained aggregates deforming by grain-size sensitive creep behave as the rheologically weak phase and localize most of the bulk strain (Kilian et al., 2011; Platt, 2015). Polycrystalline lenses of dynamically recrystallized quartz are often stronger than the feldsparderived aggregate (Tullis, 2002; Menegon et al., 2008b; Kilian et al., 2011).

Mechanisms of grain-size reduction of feldspars in quartzofeldspathic mylonites have been the subject of many studies. Results consistently showed that fluid-assisted replacement reactions occur extensively in feldspars and result in the formation of fine-grained layers of reaction products that accommodate most of the deformation (e.g. K-feldspar: Simpson and Wintsch, 1989; Tsurumi et al., 2003; Menegon et al., 2006; Fukuda et al., 2012; plagioclase: Fitz Gerald and Stünitz, 1993; Gueydan et al., 2003; Park et al., 2006; Menegon et al., 2008b; Oliot et al., 2010). It has been established that reaction weakening of feldspars is largely influenced by (1) fluid influx and chemical disequilibrium (e.g. Stünitz and Tullis, 2001; Goncalves et al., 2012) and (2) fracturing (Ree et al., 2005; Park et al., 2006; Negrini et al., 2014). In the polymineralic aggregates of reaction products grain growth is inhibited by second-phase pinning, so that the grain size is maintained sufficiently small to activate diffusion creep as the dominant deformation mechanism, thereby resulting in strain localization (Herwegh et al., 2011; Kilian et al., 2011; Menegon et al., 2015).
This contribution addresses a case study in which strain localization in the middle crust is mainly driven by brittle grain-size reduction of feldspar. The samples come from the Pernambuco shear zone (NE Brazil), where initially coarse $(>50 \mu \mathrm{m})$ feldspar porphyroclasts are intensively fractured and reduced to an ultrafine-grained mixture $(\sim 3-5 \mu \mathrm{m})$ that localizes strain in thin shear bands, while quartz deforms by dislocation creep in transposed monomineralic veins and in polycrystalline ribbons embedded in the feldspathic matrix. There is no evidence for fluid-assisted reaction weakening in feldspars.

Through the combined study of deformation microstructures and crystallographic-preferred orientations of quartz and feldspars we aim to document the microstructural modifications of a granitoid during progressive strain localization in the middle crust and to assess the bulk rheology of localized fine-grained high-strain zones. Our results have implications for the understanding of the distribution of brittle and viscous deformation mechanisms and the rheology of shear zones in the middle continental crust.

\section{Geological setting and sample description}

The Borborema Province consists of an interconnected shear zone network associated with a widespread granitic plutonism (Fig. 1; Vauchez et al., 1995). The interplay between deformation and magmatism produced an array of large-scale shear zones associated with synkinematic magmatism (Archanjo et al., 1994; Neves et al., 2000; Viegas et al., 2013). Pluton emplacement occurred at $P$ conditions of $5 \pm 1 \mathrm{Kbar}$ (Neves et al., 2000). Geochronological data (Neves, 2015, and references therein) indicate a coeval activity of magma emplacement and solid-state deformation, suggesting that the older plutonic intrusions mark the onset of shear zone nucleation in the Province.

The Pernambuco shear zone is one of the main tectonic structures of the Borborema Province and can be divided into two main E-W segments separated by the Tucano-Jatobá Basin (Fig. 1; Vauchez and Egydio-Silva, 1992): (a) a western branch composed mainly of high-grade melt-bearing orthogneisses, migmatites and synkinematic granite plutons; and (b) an eastern segment nucleated at the vicinities of two major batholiths, marked by discontinuous high- and lowtemperature mylonite belts. The dominant flow pattern along the mylonites is consistently strike-slip across a vertical flow plane although deformation perturbations have produced locally variable foliation and lineation orientations (Davison et al., 1995).

The central part of the East Pernambuco shear zone (EPSZ) is mainly composed of monzo- to granodiorite with an orthogneiss texture, showing centimetric to metric compositional layering and in abrupt contact with the host undeformed granitoid batholiths. An E-W steeply dipping mylonitic foliation is common and, where present, an 


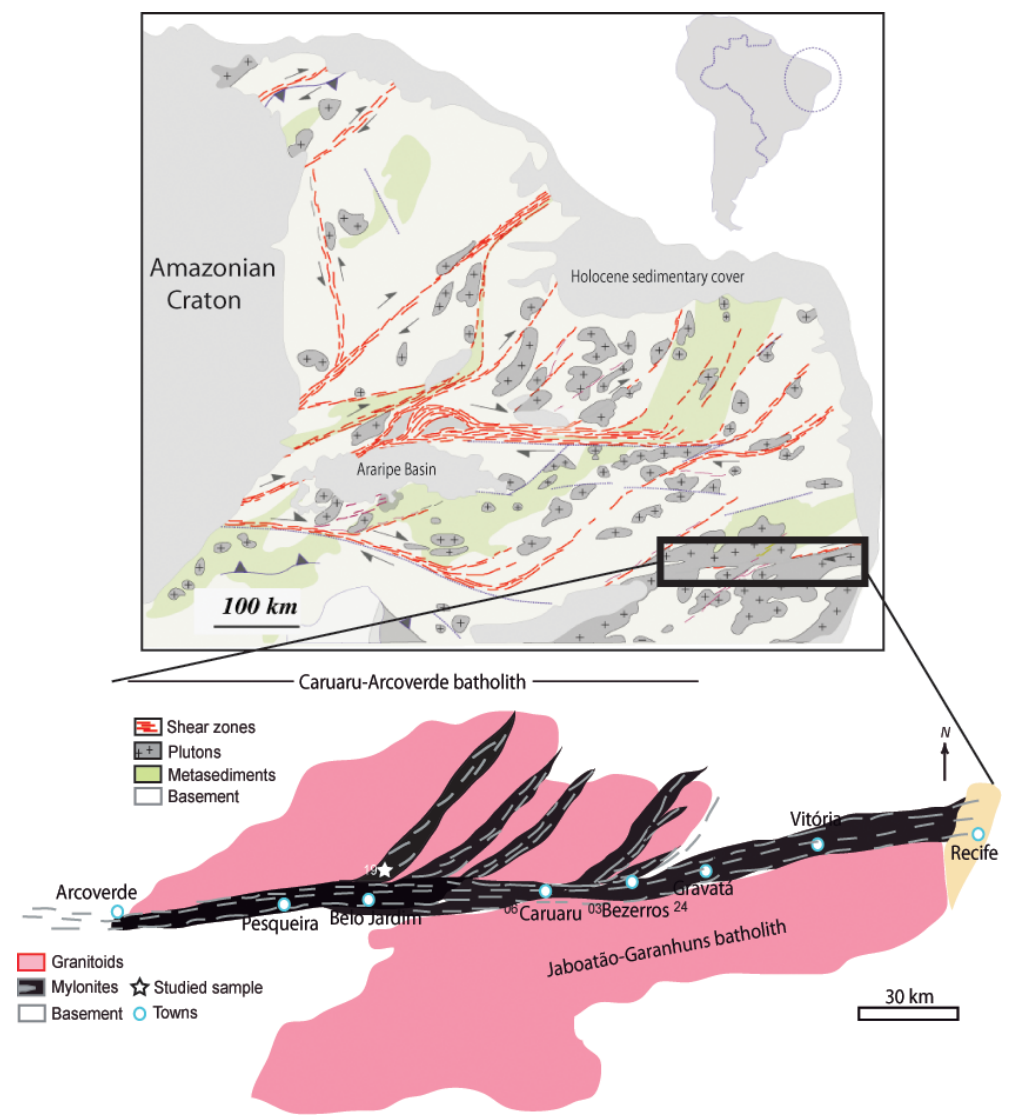

Figure 1. Geological setting of the Borborema Province, location of the Pernambuco shear zone (inset) and the sample chosen for this study (star symbol on the inset).

ENE-WSW shallow-plunging stretching lineation can be observed in quartz rods and biotite flakes. Mesoscopic shear zones can be observed at different scales, from centimetreto millimetre-thick zones of fine-grained feldspathic material (Fig. 2a), to thicker interconnected layers of quartzfeldspathic mixtures (Fig. 2b). Shear zones display steep strain gradients with sharp transitions to the undeformed granitic lithologies (Fig. 2a).

The sample chosen for this study comes from the central part of the EPSZ, in the contact between the EPSZ and $\mathrm{N}-\mathrm{NE}$ shear branches that splay off from the main structure (sample PE19; see star symbol in Fig. 1 for sample location; UTM coordinates relative to WGS84: zone 24 S, $787770 \mathrm{E}, 9081482 \mathrm{~N}$ ). The rock is a mylonitic monzogranite with equal proportions of quartz, K-feldspar and plagioclase, with biotite as the main ferromagnesian silicate. This sample was selected because it does not contain mica layers and there is no evidence of feldspar-to-mica reactions, and also because its microstructure is representative of the main hightemperature deformation $\left(550-600^{\circ} \mathrm{C}\right.$, Neves et al., 2000) observed across the length of the shear zone. Thus, the sample provides the opportunity to investigate grain-size reduc- tion and weakening of feldspathic rocks in the absence of mineral reactions during shearing at mid-crustal conditions.

The overall microstructure is characterized by coarse $(>50 \mu \mathrm{m})$ feldspar porphyroclasts immersed in a fine-grained $(<20 \mu \mathrm{m})$ quartz-feldspathic matrix (Fig. 3). The matrix is typically localized in dark, fine-grained ultramylonitic bands that form interconnected layers wrapping around feldspar porphyroclasts and typically forming an SC' fabric consistent with a sinistral sense of shear (Figs. 2, 3).

Feldspar (K-feldspar, albitic plagioclase and perthites) porphyroclasts have rounded to sub-elliptical shapes and commonly contain intragranular fractures. Fractures either form conjugate sets or occur in one dominant set parallel to the trace of the C' bands. Feldspar fracturing is pervasive so that the sample locally shows a cataclastic texture with highly fractured feldspathic domains in abrupt contact with fine-grained aggregates (Fig. 3). The fractures show variable thicknesses and are typically filled by an ultrafine-grained $(<10 \mu \mathrm{m})$ feldspathic matrix. Porphyroclasts are locally separated to form bookshelf geometries where the fractures are parallel to the C' shear bands observed at the bulk sample scale (Fig. 3). Quartz occurs as (i) dynamically recrystallized, thick (up to $5 \mathrm{~mm}$ ), foliation (S)-parallel monominer- 

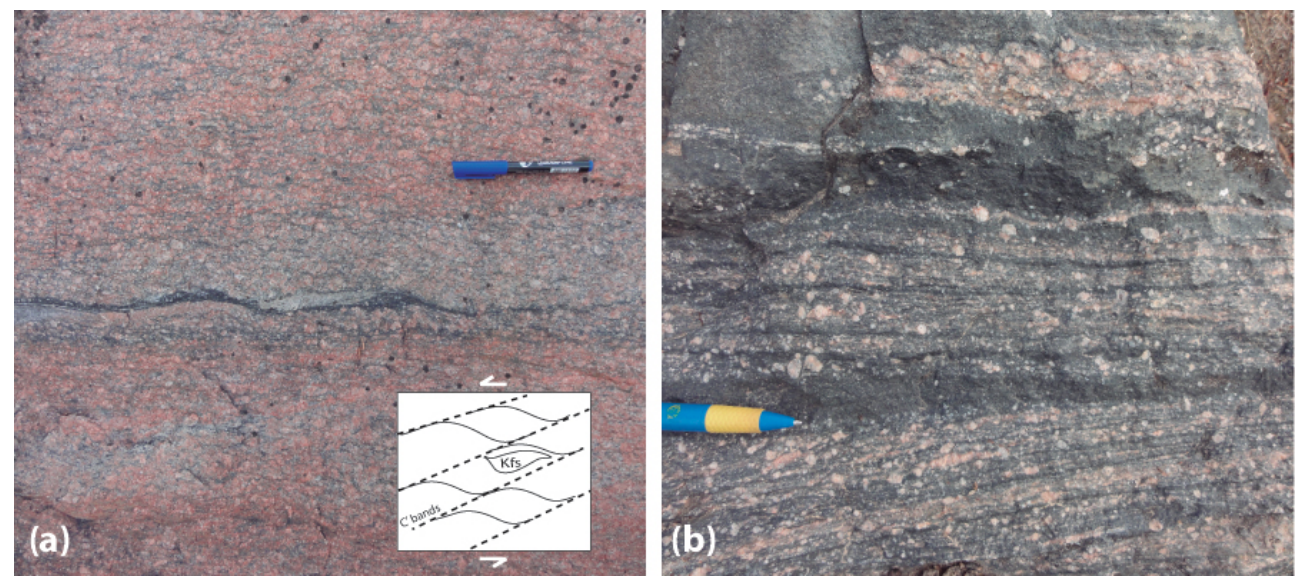

Figure 2. Field observations of shear zones in mylonitic granitoids of the Pernambuco shear zone. (a) Fine-grained feldspar aggregates in shear bands; the inset highlights the geometrical relationship of the foliation and C' bands. (b) Two-feldspar mixtures characterized by fine-grained feldspar grains, feldspar porphyroclasts and quartz ribbons.

alic veins and (ii) thin $(\sim 10 \mu \mathrm{m})$ dynamically recrystallized polycrystalline ribbons embedded in the ultrafine-grained feldspathic matrix.

\section{Methods}

\subsection{Microstructural analysis}

Oriented polished thin sections were cut in the $X Z$ plane of the structural reference frame, perpendicular to the foliation $(Z)$ and parallel to the lineation $(X)$. Initial microstructural characterization was carried out with polarized light microscopy. Backscattered electron (BSE) images were acquired with a Jeol-6610 and a Jeol-7001FEG SEM at the Electron Microscopy Centre, Plymouth University. The proportion and distribution of individual phases were studied on grain boundary maps constructed on SEM-BSE digitized images and on maps derived with electron backscatter diffraction (EBSD) using the Image SXM software package (available at http://www.ImageSXM.org.uk).

Grain-size distributions were analysed using grain boundary maps derived from manual grain contouring of SEMBSE images and EBSD maps. The grain size was calculated with Image SXM as the diameter of the circle with the area equivalent to that of the grain. Grain boundaries were also identified automatically on EBSD maps as high angle boundaries with misorientation higher than $10^{\circ}$. In order to avoid second-phase effects on the grain-size analysis of recrystallized quartz, only grains completely surrounded by grain boundaries were considered in the construction of grain boundary maps. Grains in contact with different phases were excluded from the data set, since their recrystallized size might have been influenced by second-phase pinning (Herwegh et al., 2011).
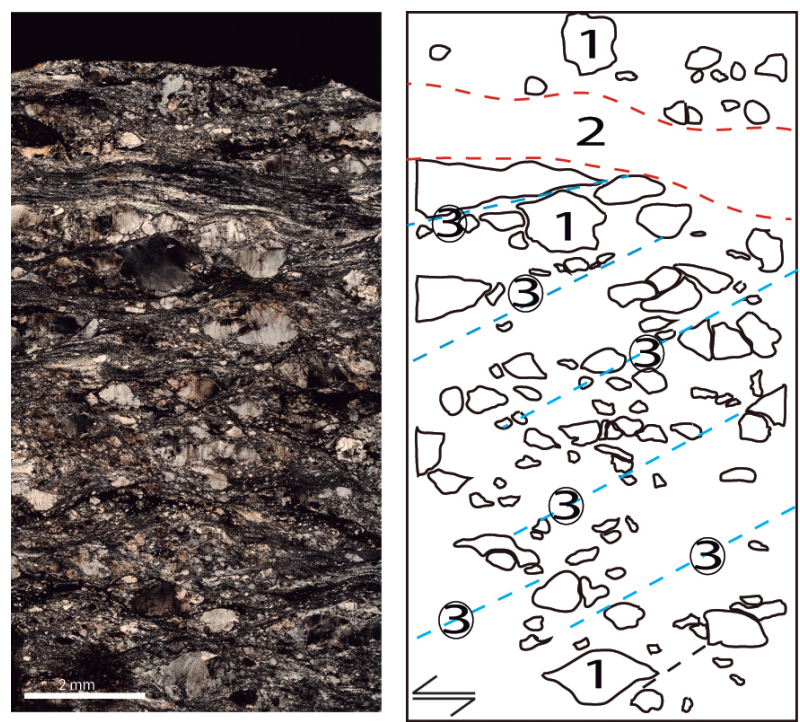

Figure 3. Cross-polarized optical micrograph showing the microstructure of sample PE19 from the Pernambuco shear zone. Kfeldspar porphyroclasts (domain 1) alternate with monomineralic quartz veins (domain 2). Dark layers of ultrafine-grained feldspathic mixture form an anastomosing network wrapping the porphyroclasts and are particularly well developed in a C' orientation consistent with the sinistral sense of shear (domain 3). See text for further explanations.

\subsection{Mineral chemistry}

Chemical composition of feldspars (porphyroclasts and recrystallized grains in fractures and C' bands) was determined through electron probe microanalysis at Géosciences Montpellier. Analytical conditions were $20 \mathrm{kV}, 10 \mathrm{nA}$ and a beam size of $1 \mu \mathrm{m}$. 


\subsection{EBSD analysis}

Crystallographic-preferred orientations were obtained through EBSD analysis at Plymouth University. Thin sections were polished with colloidal silica using a vibratory polishing machine to remove surface damage induced by mechanical polishing. Polished thin sections were then carbon coated and analysed with a Jeol-6610 SEM at the Electron Microscopy Centre, Plymouth University. Working conditions during acquisition of EBSD patterns were $20 \mathrm{kV}$ accelerating voltage, $20-23 \mathrm{~mm}$ working distance and $70^{\circ}$ sample tilt. EBSD patterns were acquired on rectangular grids using step sizes ranging from 0.5 to $2 \mu \mathrm{m}$ depending on grain size in the area of interest. EBSD data were processed using the Oxford Instruments CHANNEL5 software to generate phase and crystallographic maps and misorientation angle distributions. Crystallographic orientation data were plotted using David Mainprice's PF_ctf freeware application (available at http://www.gm.univ-montp2.fr/PERSO/mainprice/W_data/ CareWare_Unicef_Programs/Most_recent_Core_Package_ Mac_INTEL_OS10.9_apps/PF_ctf.app/).

\subsection{Results}

\subsection{Deformation microstructures and grain-size analysis}

The sample PE19 has an overall sinistral SC' fabric, where variably fractured feldspar porphyroclasts are embedded in an anastomosing network of ultrafine-grained dark bands. A $0.5 \mathrm{~cm}$ thick recrystallized quartz vein is transposed along the $\mathrm{S}$ foliation; C' bands do not continue into the vein (Fig. 3). The three following microstructural domains will be described separately (Fig. 3):

- Domain 1: feldspar porphyroclasts;

- Domain 2: recrystallized quartz vein;

- Domain 3: C' shear bands.

\subsubsection{Domain 1: feldspar porphyroclasts}

Feldspar porphyroclasts have elliptical to sub-elliptical shapes and variable sizes of $50 \mu \mathrm{m}-1 \mathrm{~mm}$ (Figs. 3, 4). Most porphyroclasts are single grains, but some are fragments resulting from fracturing of initially larger grains (Fig. 4a). The main solid-state deformation microstructures are undulose extinction and mechanical twinning; bent twins can be locally observed in plagioclase grains.

Porphyroclasts are invariably fractured (Figs. 3, 4a, b). Some fractures crosscut the entire porphyroclast, while some terminate within the grain. Locally, fractures form dense networks that dissect the porphyroclasts into fine-grained fragments $(<25 \mu \mathrm{m})$ in a microstructure that resembles a cataclastic texture (Figs. $4 \mathrm{a}-\mathrm{c}$ ). The fragments show angular, cus- pate and sub-elliptical shapes. Synthetic and antithetic bookshelf structures formed by the stacking of individual fragments are common. Synthetic bookshelf systems are more frequent and the fractures separating individual fragments are, in this case, parallel to the macroscopic C' bands of the mylonitic foliation.

Fractures are typically a few microns thick, but the thickness locally increases to up to $100 \mu \mathrm{m}$ when the fractures grade to intracrystalline bands filled with ultrafine $(<10 \mu \mathrm{m}) \mathrm{K}$-feldspar + albite mixtures and with larger $(>10 \mu \mathrm{m})$ feldspar fragments (Figs. $4 \mathrm{~b}-\mathrm{e}$ ). The average size of the grains filling the fractures is $3-4 \mu \mathrm{m}$ (Fig. 7a). Relatively larger fragments (grain size $>10 \mu \mathrm{m}$ ) preferentially occur at the margins of the fracture, and the grain size decreases to $\sim 3 \mu \mathrm{m}$ towards the centre of the fracture (Fig. $4 \mathrm{~d}$ ). Intracrystalline bands originating from intracrystalline fractures are transitional to thicker $(500 \mu \mathrm{m}-1 \mathrm{~mm})$ transgranular bands oriented both along C' shear bands and forming an anastomosing network wrapping around large and variably fractured porphyroclasts (Figs. 3, 4e). Some of the fractures that crosscut porphyroclasts are filled by almost monomineralic albite aggregates with average grain size of $\sim 3 \mu \mathrm{m}$ (Fig. 4f).

Feldspar porphyroclasts are never, not even partially, replaced by mica-rich aggregates; the only reaction products observed in K-feldspar porphyroclasts are some rare myrmekite intergrowths.

\subsubsection{Domain 2: recrystallized quartz veins}

In the field, up to $5 \mathrm{~mm}$ thick deformed quartz veins parallel to the mylonitic $\mathrm{S}$ foliation are common. In the vein within sample PE19, quartz occurs as variably elongated monocrystalline ribbons up to $1 \mathrm{~mm}$ in length (mostly concentrated in the inner part of the vein) mantled by recrystallized aggregates (Fig. 5a). Monocrystalline crystals elongated parallel to the foliation show undulose extinction and serrated grain boundaries; they contain subgrains 10-20 $\mu \mathrm{m}$ in size and subgrain boundaries both parallel and normal to the main grain elongation. Recrystallized grains have generally an equant or slightly elongated shape parallel to the foliation (Fig. 5a), and show serrated and sutured grain boundaries. The average grain size of recrystallized grains is $15-20 \mu \mathrm{m}$ (Fig. 8a).

When in contact with variably fractured feldspar porphyroclasts, the quartz veins wrap them and partially fill the dilatant sites between fragments, such as boudin necks and large fractures. At the vein-porphyroclast contacts, quartz recrystallizes to a slightly finer grain size $(\sim 15-10 \mu \mathrm{m})$ than that observed in the interior of the veins. At the contact with the fine-grained feldspathic matrix, the recrystallized quartz grain size locally decreases to about $8-10 \mu \mathrm{m}$. The contacts with the fine-grained matrix show lobate and cuspate interfaces over distances of $<10 \mu \mathrm{m}$, typically with $\mathrm{K}$ feldspar grains forming protrusions towards quartz-quartz grain boundaries. 

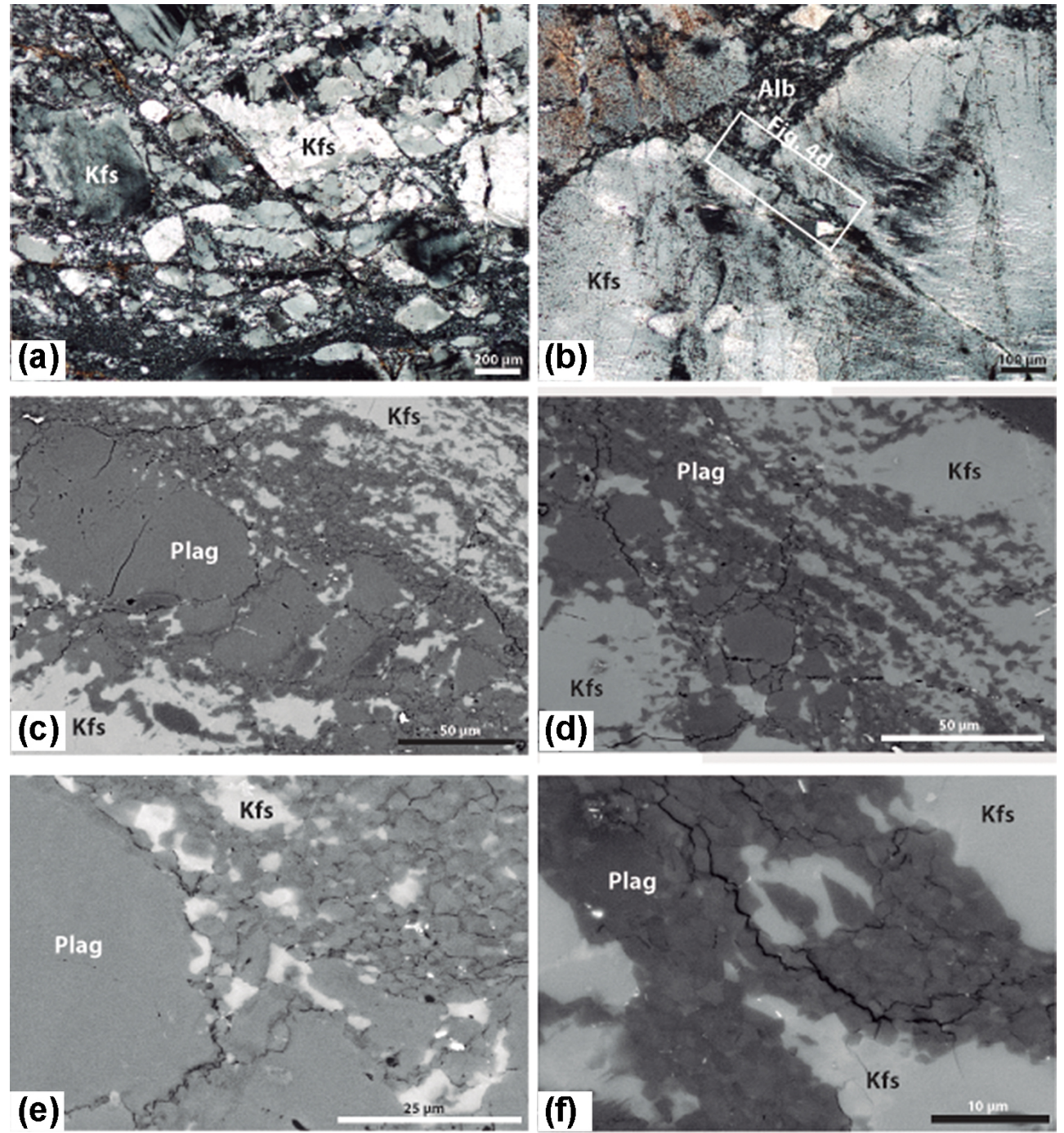

Figure 4. BSE images of microstructures of feldspar porphyroclasts: (a) cataclastic texture generated by fracturing and further disaggregation of feldspar porphyroclasts into fragments with heterogeneous grain size; (b) intracrystalline fractures in feldspar porphyroclast filled by finegrained two-feldspar mixtures; (c) set of parallel fractures cutting plagioclase porphyroclast; (d) detail of Fig. $4 \mathrm{~b}$ showing the filling of a feldspar fracture; (e) tail of fine-grained plagioclase + K-feldspar around plagioclase porphyroclasts; (f) detail of the feldspar fracture showing the infill by an almost pure plagioclase aggregate.
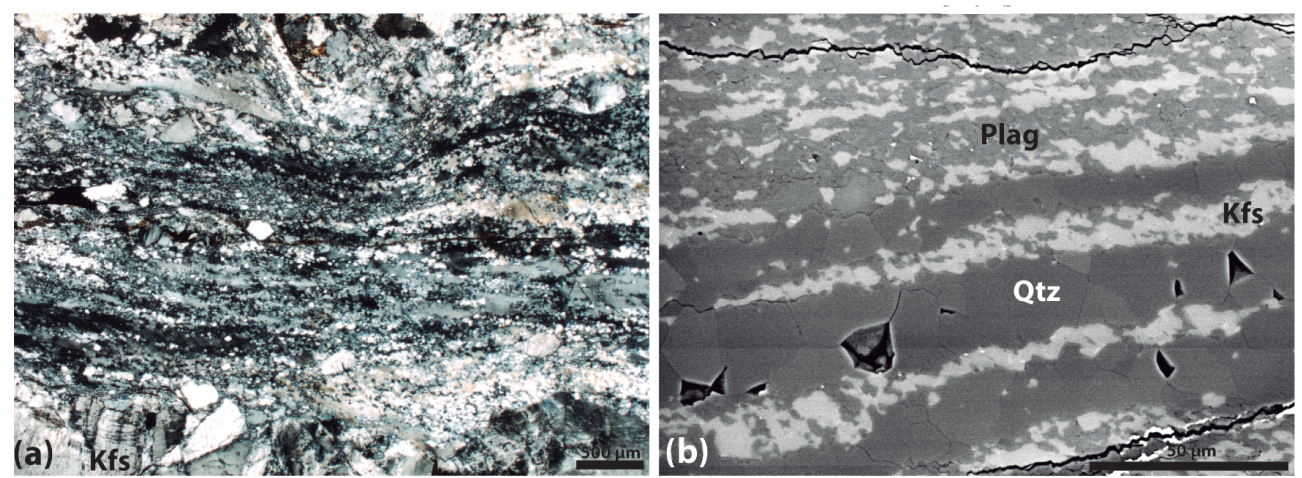

Figure 5. Optical and SEM microstructures of quartz veins and ribbons: (a) quartz monomineralic vein in contact with feldspar porphyroclasts; (b) SEM-BSE image of a C' band showing the overall distribution of phases in the contact with the quartz ribbon. 

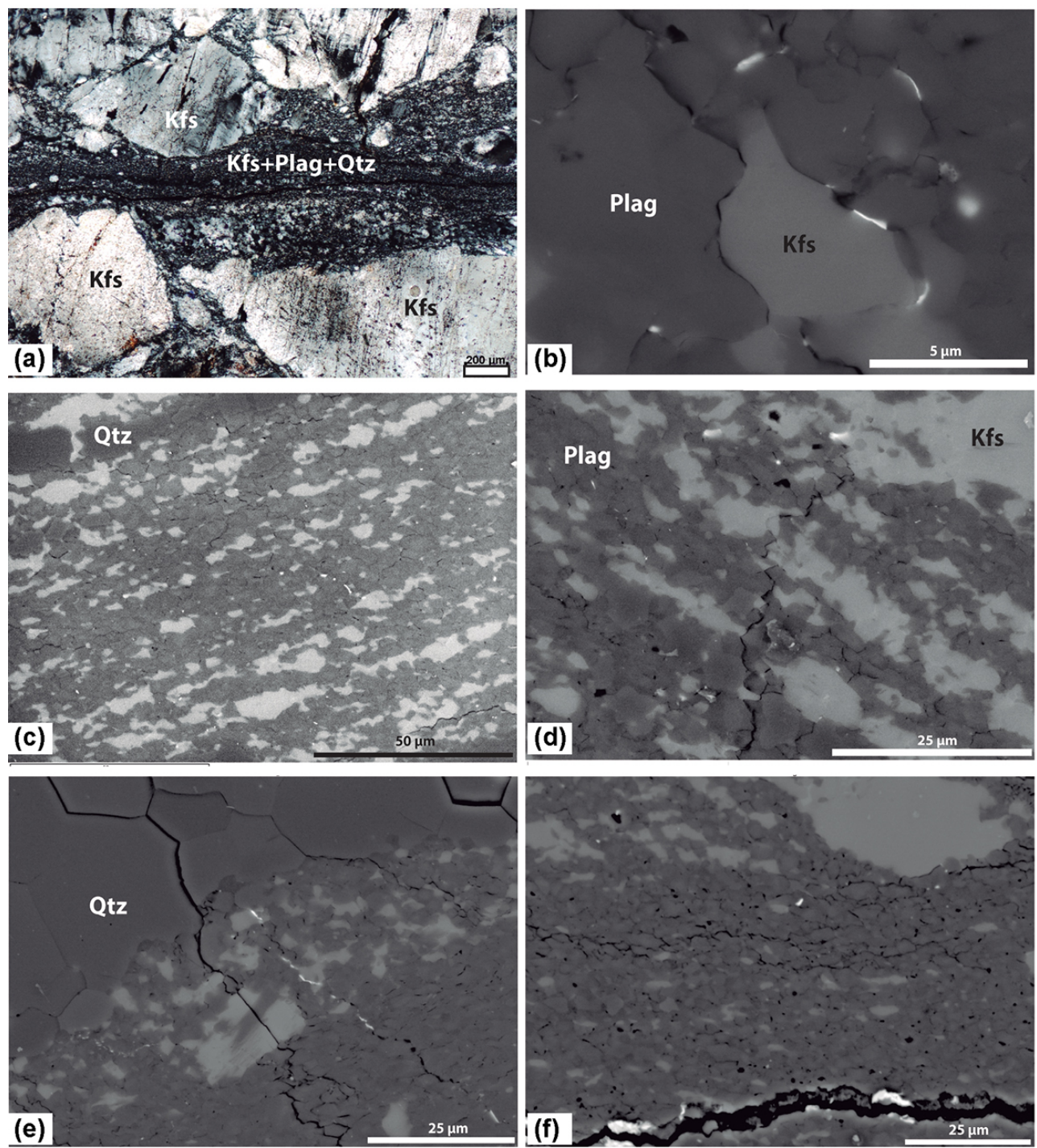

Figure 6. Optical and SEM microstructures of the C' shear bands. (a) Optical micrograph of a C' band showing its boundaries with feldspar porphyroclasts; quartz ribbons are embedded in the band. (b) Boundary geometry of fine-grained K-feldspar and plagioclase grains in the matrix. (c-f) Details of the fine-grained feldspathic mixture in the C' bands. Overall grain size is 3-6 $\mu \mathrm{m}$.

\subsubsection{Domain 3: C' shear bands}

K-feldspar and plagioclase in the ultrafine-grained C' bands show similar microstructures as the matrix filling intracrystalline fractures within feldspar porphyroclasts (Figs. 4d-f, $6 a-c)$.

The thick $(500 \mu \mathrm{m}-1 \mathrm{~mm}) \mathrm{C}^{\prime}$ bands consist of ultrafinegrained K-feldspar + plagioclase (average grain size of both phases on the order of $3 \mu \mathrm{m}$; Figs. $7 \mathrm{~b}, \mathrm{c}) \pm$ polycrystalline quartz ribbons (Figs. 5b, 6). Feldspar grains have a subelliptical to sub-equant shape (Figs. 4c-f, 6b-f). K-feldspar is slightly coarser (average grain size $3.5 \mu \mathrm{m}$ ) than plagioclase (average $3 \mu \mathrm{m}$ ). The distribution of the two phases in the matrix is heterogeneous; whilst plagioclase is homogeneously distributed in the inner parts of the bands, K-feldspar appears more dispersed and locally accumulates in the periphery of the bands (Fig. 6c-e), commonly in contact with quartz ribbons and/or feldspar porphyroclasts.

Thin ribbons $(<25 \mu \mathrm{m}$ in thickness) of polycrystalline quartz embedded in the feldspathic matrix are common (Figs. 5b, 6a). The ribbons are fully recrystallized and only a few grains thick (usually less than 3-4 grains). Quartz grain size is slightly smaller $(\sim 5-8 \mu \mathrm{m})$ than in the recrystallized vein $(\sim 15-20 \mu \mathrm{m})$. The core of the ribbons is mainly composed by $\sim 6 \mu \mathrm{m}$ sub-equant to sub-elliptical grains with curved to straight boundaries. Larger grains (up to $10-15 \mu \mathrm{m}$ in length) are typically elongated parallel to the band boundaries, whereas smaller grains $(<5 \mu \mathrm{m}$ in size $)$ are usually 

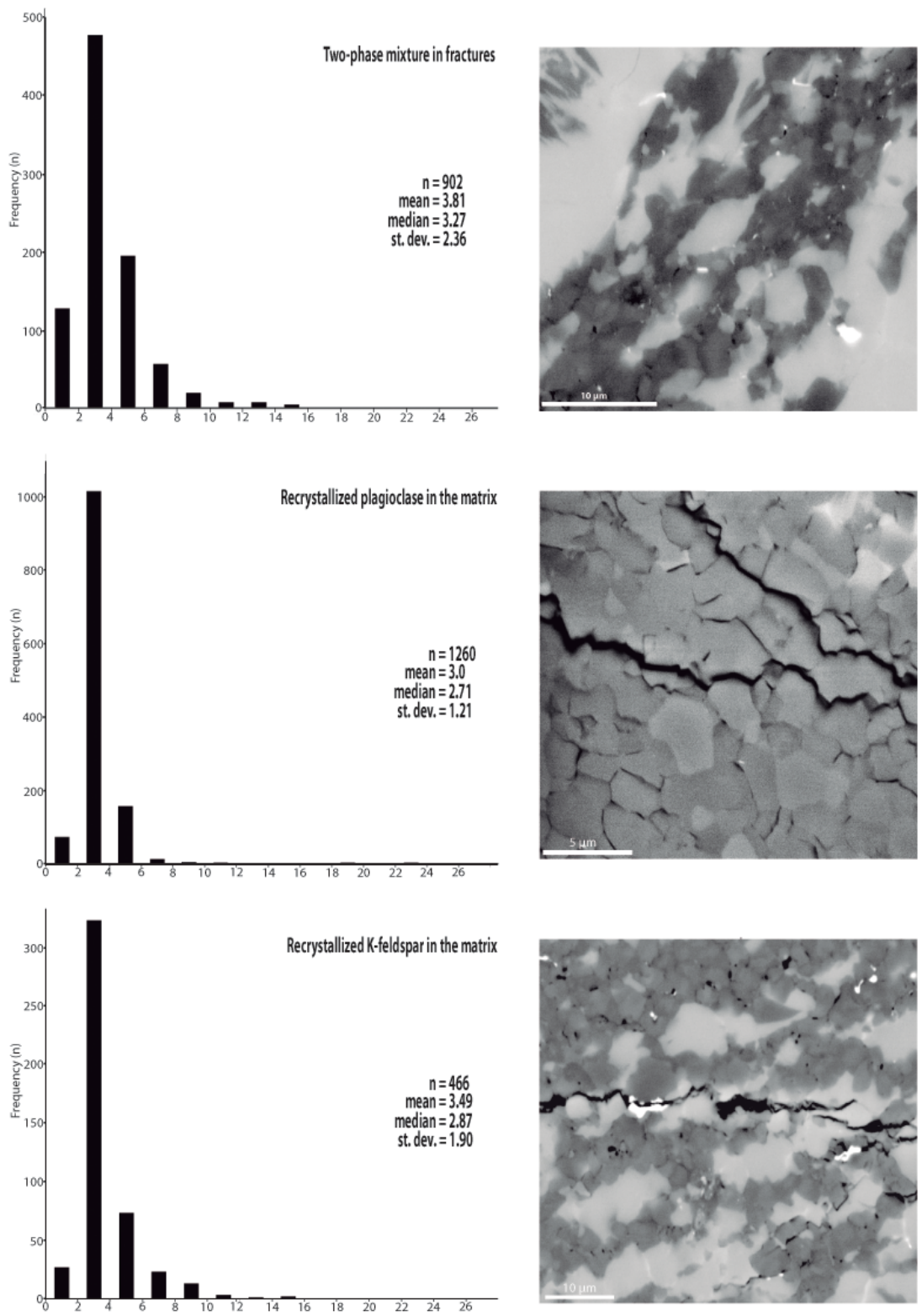

Figure 7. Grain-size histograms for recrystallized feldspars as mixtures in the fractures and as individual phases in the matrix.

present at triple junctions and distributed along the ribbon boundaries at the contact with the feldspathic matrix.

The ribbon-matrix contacts are lobate and cuspate, with small grains $(<5 \mu \mathrm{m})$ of $\mathrm{K}$-feldspar and plagioclase forming protrusion towards the quartz grains (Figs. 5b, 6c, e). Locally, plagioclase and K-feldspar crystallize in triple junctions and along quartz grain boundaries, so that quartz ribbons appear partially separated and discontinuous (Figs. 5b, 8).

Quartz ribbons and layers of feldspathic matrix may locally define a compositional banding parallel to the C' band boundaries. We have not observed boudinage, pinch-andswell or buckling of any of the layers.
In the ultrafine-grained bands, quartz also occurs as small $(\sim 5 \mu \mathrm{m})$ grains dispersed in the feldspathic matrix. These are commonly individual equant grains localized at triple junctions. Less commonly, dispersed quartz defines clusters or trails oriented parallel to the band boundaries (Figs. 8, 13). Within polycrystalline clusters, some quartz grains are partially separated by fine-grained plagioclase or K-feldspar present along quartz-quartz grain boundaries (Figs. 8, 13). 


\subsection{Mineral chemistry}

Representative chemical analyses of feldspar porphyroclasts and recrystallized grains in the intracrystalline fractures and in the C' shear bands are given in Table 1 . The chemical composition of feldspar is shown in Fig. 9.

K-feldspar porphyroclasts are more abundant than plagioclase and their composition ranges between Or$_{85}$ and Or$_{95}$. The compositional range of the recrystallized grains (both filling the intracrystalline fractures and occurring in the C' shear bands) overlaps with the composition of the porphyroclasts, although the limited amount of measurements does not yield definitive conclusions. The limited amount of measurements is due to the ultrafine size of the recrystallized grains, so that some analyses were discarded as they were clearly mixed compositions.

Plagioclase porphyroclasts are of albite and oligoclase composition $\left(\mathrm{An}_{1-14}\right)$. Although narrower $\left(\mathrm{An}_{3-9}\right)$, the range of chemical composition of the recrystallized grains overlaps with the composition of the porphyroclasts. However, as for K-feldspar, it was possible to collect only a limited amount of compositional data.

\subsection{EBSD analysis}

\subsubsection{Domain 1: feldspar porphyroclasts}

Figure 10a shows an EBSD-derived phase map of an intracrystalline fracture zone within a perthite porphyroclast (Fig. 4b). The five K-feldspar fragments included in the map (we considered fragments those with grain size larger than $15 \mu \mathrm{m}$, see Fig. 7) are oriented with (001) subparallel to the $X Y$ and $Z Y$ planes of the finite strain ellipsoid (Fig. 10c). The poles to (001) form clusters located between $Z$ and $X$ directions and are slightly rotated with the overall sinistral shear sense. There is a strong degree of overlap between the crystallographic orientation of the fragments and of the fine grains filling the fracture.

Fine plagioclase grains also overlap in orientation with the porphyroclast fragments. The overlap is particularly evident for the poles to the (001) planes (Fig. 10c).

The internal misorientation of plagioclase and K-feldspar grains (both porphyroclast fragments and fine recrystallized grains) is generally very low, on the order of $1^{\circ}$ (Fig. 11a). There are no clear recovery features (subgrains) in the porphyroclast fragments (Fig. 11a).

Misorientation angle distributions (MADs) of fine grains display peaks of misorientations $<30^{\circ}$ for both feldspars, with a dominance of $10-15^{\circ}$ misorientations for K-feldspar, while plagioclase shows a peak of misorientations $<5^{\circ}$ (Fig. 11b). In K-feldspar, there are peaks of misorientations at $100-115$ and also at $150-160^{\circ}$. For plagioclase, no significant deviations from the random distribution are observed apart from the $<5^{\circ}$ misorientations. Misorientation profiles orthogonal to the intracrystalline bands of re- crystallized grains show large misorientation angles at the porphyroclast-band boundaries and among the fine grains within the bands (Fig. 11c).

\subsubsection{Domain 2: quartz in monomineralic veins}

The crystallographic map of quartz in the monomineralic vein shows elongated monocrystalline crystals that contain subgrains of similar size as the surrounding recrystallized grains (Fig. 12a). Recrystallized grains have a strong crystallographic-preferred orientation (COP) of the $c$ axis, which forms a maximum along the $Y Z$ plane close to the $Y$ direction (Fig. 12c). The sharp clusters of all crystallographic directions are consistent with a "single-crystal" CPO (Schmid and Casey, 1986). The inverse pole figure map with respect to the foliation normal (Fig. 12a) shows that the elongate monocrystalline grains have $c$ axis orientations clustered around the $Y$ direction, while the recrystallized grains have $c$ axes more scattered between $Y$ and $Z$.

The misorientation angle distribution deviates significantly from the theoretical random distribution both for correlated and uncorrelated pairs (Fig. 12b). Misorientation angles between 5 and $45^{\circ}$ are more frequent than in the random distribution, whereas high misorientation angles are less frequent.

\subsubsection{Domain 3: fine-grained polyphase aggregate in C' shear bands}

The polyphase aggregate in C' shear bands dominantly consists of a biphasic mixture of ultrafine-grained plagioclase and K-feldspar, with a minor amount of scattered quartz grains. A monomineralic, polycrystalline quartz ribbon is also included in the EBSD-derived phase map shown in Fig. 13a. The average internal misorientation of feldspars is less than $1^{\circ}$ (Fig. 13b).

$\mathrm{K}$-feldspar in the ultrafine-grained aggregate shows no clear $\mathrm{CPO}$ ( $\max =2.5$ multiples of the uniform distribution: Fig. 13c). Recrystallized plagioclase has a better defined but still weak CPO with concentrations of poles to (100) close to the stretching lineation $(X)$, while poles to $(010)$ form a girdle distribution along $Y$ and $Z$ (Fig. 13c).

The recrystallized quartz ribbon displays a similar CPO to the monomineralic quartz veins, with a strong clustering of $c$ axes close to the $Y$ direction (Fig. 13c). Dispersed finegrained quartz in the feldspathic matrix displays clusters of $c$ axes close to $Y$ and between $X$ and $Z$. The peripheral cluster extends from near $X$ for about $45^{\circ}$ towards $Z$ and is subparallel to the instantaneous stretching axis for a sinistral sense of shear (Fig. 13c).

The uncorrelated misorientation angle distribution of the two feldspars in the fine-grained mixture does not show significant deviations from the random distribution (Fig. 14). The observed peaks of misorientations close to $180^{\circ}$ in plagioclase are most likely related to twins. 
Table 1. Representative chemical compositions of feldspar porphyroclasts and recrystallized grains.

\begin{tabular}{|c|c|c|c|c|c|c|}
\hline \multirow[b]{2}{*}{ Weight (\%) } & \multicolumn{2}{|c|}{ Porphyroclasts } & \multicolumn{2}{|c|}{ C' shear bands } & \multicolumn{2}{|c|}{$\begin{array}{l}\text { Intracrystalline } \\
\text { fractures }\end{array}$} \\
\hline & $\mathrm{Kfs}$ & Plag & Plag & Kfs & Plag & $\mathrm{Kfs}$ \\
\hline $\mathrm{SiO}_{2}$ & 63.99 & 69.94 & 66.72 & 62.72 & 67.16 & 63.62 \\
\hline $\mathrm{TiO}_{2}$ & 0.01 & 0.00 & 0.00 & 0.00 & 0.00 & 0.02 \\
\hline $\mathrm{Al}_{2} \mathrm{O}_{3}$ & 18.66 & 20.29 & 21.16 & 18.53 & 20.85 & 18.54 \\
\hline $\mathrm{Cr} 2 \mathrm{O} 3$ & 0.00 & 0.00 & 0.02 & 0 & 0.00 & 0.00 \\
\hline $\mathrm{FeO}$ & 0.00 & 0.01 & 0.05 & 0.02 & 0.03 & 0.00 \\
\hline $\mathrm{MnO}$ & 0.00 & 0.01 & 0.00 & 0.00 & 0 & 0.00 \\
\hline $\mathrm{MgO}$ & 0.00 & 0 & 0.01 & 0 & 0.00 & 0.00 \\
\hline $\mathrm{CaO}$ & 0.00 & 0.13 & 1.76 & 0.11 & 1.13 & 0.01 \\
\hline $\mathrm{Na}_{2} \mathrm{O}$ & 0.48 & 9.89 & 9.24 & 0.52 & 9.95 & 0.68 \\
\hline $\mathrm{K}_{2} \mathrm{O}$ & 16.95 & 1.41 & 0.24 & 15.76 & 0.19 & 16.18 \\
\hline Total & 100.11 & 101.69 & 99.19 & 97.67 & 99.32 & 99.05 \\
\hline \multicolumn{7}{|c|}{ No. of cations on the basis of eight oxygens } \\
\hline $\mathrm{Si}$ & 2.97 & 3.00 & 2.94 & 2.97 & 2.95 & 2.98 \\
\hline $\mathrm{Ti}$ & 0.00 & 0.00 & 0.00 & 0.00 & 0.00 & 0.00 \\
\hline $\mathrm{Al}$ & 1.02 & 1.03 & 1.10 & 1.03 & 1.08 & 1.02 \\
\hline $\mathrm{Cr}$ & 0.00 & 0.00 & 0.00 & 0.00 & 0.00 & 0.00 \\
\hline $\mathrm{Fe}$ & 0.00 & 0.00 & 0.00 & 0.00 & 0.00 & 0.00 \\
\hline $\mathrm{Mn}$ & 0.00 & 0.00 & 0.00 & 0.00 & 0.00 & 0.00 \\
\hline $\mathrm{Mg}$ & 0.00 & 0.00 & 0.00 & 0.00 & 0.00 & 0.00 \\
\hline $\mathrm{Ca}$ & 0.00 & 0.01 & 0.08 & 0.01 & 0.05 & 0.00 \\
\hline $\mathrm{Na}$ & 0.04 & 0.82 & 0.79 & 0.05 & 0.85 & 0.06 \\
\hline K & 1.00 & 0.08 & 0.01 & 0.95 & 0.01 & 0.97 \\
\hline Total & 5.04 & 4.93 & 4.92 & 5.01 & 4.94 & 5.03 \\
\hline $\mathrm{An} \%$ & 0.00 & 0.67 & 9.36 & 0.55 & 5.85 & 0.07 \\
\hline $\mathrm{Ab} \%$ & 4.13 & 90.81 & 89.14 & 4.77 & 92.99 & 5.98 \\
\hline Or\% & 95.87 & 8.52 & 1.50 & 94.68 & 1.16 & 93.95 \\
\hline
\end{tabular}

The misorientation angle distribution in the quartz ribbon shows deviations from the random distribution, with main peaks at $6-8,16-18$ and $50-54^{\circ}$ (Fig. 14). In the scattered fine-grained quartz, the uncorrelated distribution is remarkably close to the theoretical random curve.

\section{Discussion}

\section{1 $P, T$, fluid conditions of deformation}

The mylonitic granitoid in sample PE19 is part of a magmatic- to solid-state shear zone developed in the vicinities of two granitoid batholiths (Vauchez et al., 1995). Temperature and pressure conditions during strike-slip deformation have been previously reported in literature from geothermobarometry and thermodynamic modelling based on the mineral assemblage sillimanite + garnet + plagioclase in mylonitic schists (Neves et al., 2000). $P$ and $T$ estimates using the THERMOCALC software yielded temperature values of $575-650{ }^{\circ} \mathrm{C}$ in mylonitic mica schists, while the edenite-richterite thermometer of Holland and Blundy (1994) was applied in mylonitic granitoids, giving temperatures in the range of $670-700^{\circ} \mathrm{C}$ and mean pressures of 5.7 Kbar (see Fig. 15 in Neves et al., 2000).

In our sample, deformation temperatures can be qualitatively assessed using the quartz microstructures and inferred slip systems. The use of quartz recrystallization microstructures and CPO to estimate pressure and temperature conditions has been widely applied in different studies of mylonitic granites in shear zones (Tommasi et al., 1994; Stipp et al., 2002, 2010; Zibra et al., 2012). However, this approach has to be taken with caution because quartz microstructures are also sensitive to water content (Mancktelow and Pennacchioni, 2004; Menegon et al., 2011) and strain rate (Stipp et al., 2002).

Quartz microstructure and CPO in the monomineralic vein (Figs. 5, 12) and in the ribbon in the C' band (Fig. 13) are consistent with recrystallization-accommodated dislocation creep and with the dominant activity of rhomb $\langle a\rangle$ and prism $\langle a\rangle$ slip systems. The recrystallization microstructure, 

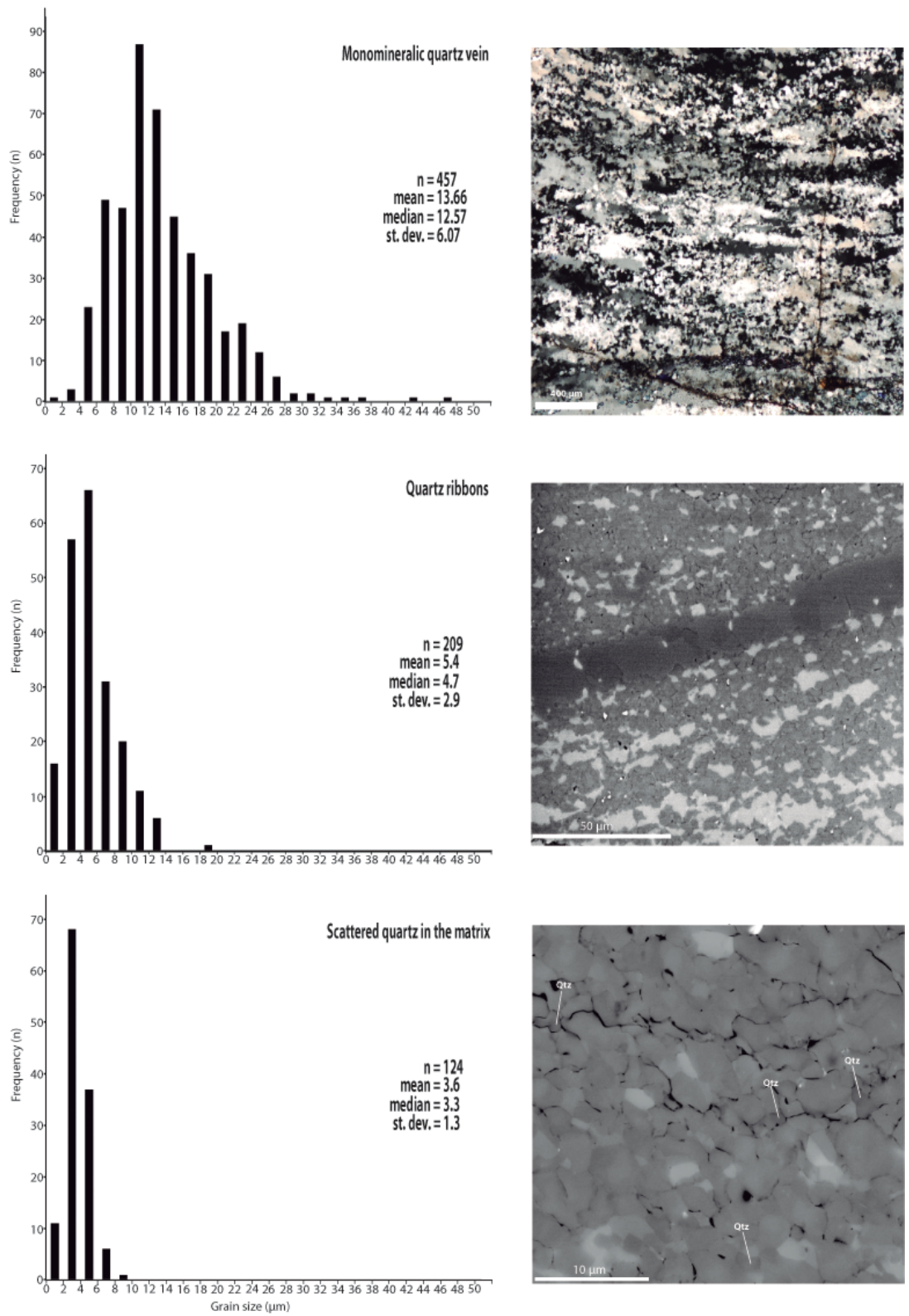

Figure 8. Grain-size histograms for quartz in the different domains - monomineralic veins, ribbons and scattered in the feldspathic matrix.

characterized by elongated monomineralic ribbon grains and by a mantle of polygonal recrystallized grains, is consistent with subgrain rotation recrystallization. Overall, the microstructure and $\mathrm{CPO}$ suggest $T$ around $500-550^{\circ} \mathrm{C}$ (e.g. Stipp et al., 2002; Pennacchioni et al., 2010). This $T$ estimate is somewhat lower than the estimate of Neves et al. (2000). However, temperatures in excess of $650{ }^{\circ} \mathrm{C}$ are typically associated with a markedly different quartz microstructure, characterized by large grain size, extensive grain boundary migration, chessboard subgrain pattern and a $c$ axis CPO with an $X$ max resulting from the activity of prism $\langle c\rangle$ (e.g. Stipp et al., 2002; Zibra et al., 2012). Zibra et al. (2012) con- ducted an extensive mapping of quartz $\mathrm{CPO}$ in shear zones formed during transitional magmatic- to solid-state deformation. Their results indicate that the activation of prism $\langle a\rangle$ in quartz is typical of solid-state deformation conditions at temperatures of $\sim 500^{\circ} \mathrm{C}$ and pressures of $4.5-5 \mathrm{kbar}$.

Based on the comparison between $T$ estimates of Neves et al. (2000) and our own data set, we conclude that the mylonitization in Pernambuco shear zone recorded in sample PE19 occurred at temperatures of $500-550{ }^{\circ} \mathrm{C}$ and pressure of 4.5-5 kbar. The higher $T$ estimated by Neves et al. (2000) may indicate that the Eastern Pernambuco Shear Zone was active during progressive cooling of the syntectonic plutons 

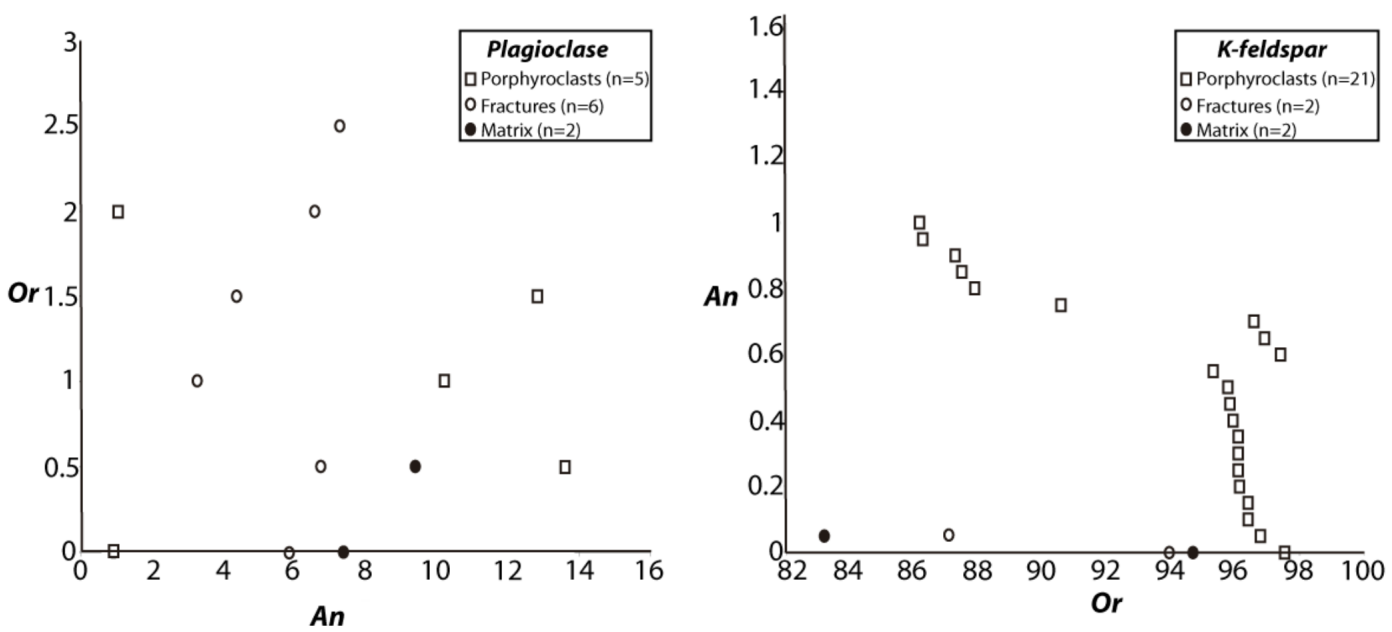

Figure 9. Chemical compositions of plagioclase and K-feldspar in the porphyroclasts and as recrystallized grains inside fractures and in the matrix.
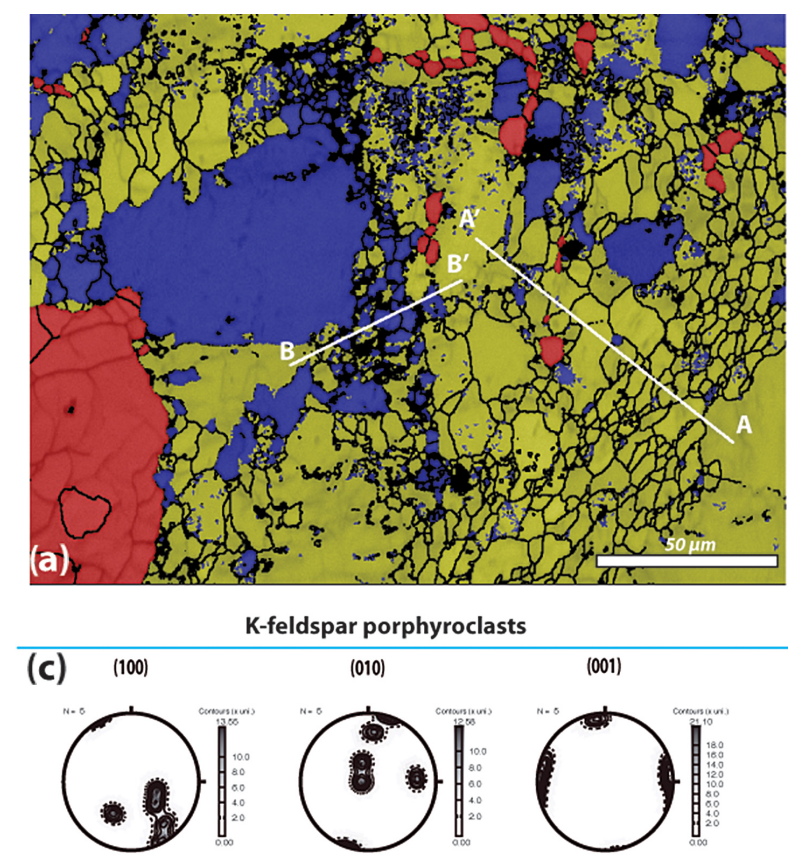

Recrystallized K-feldspar
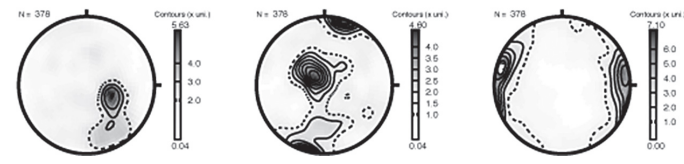

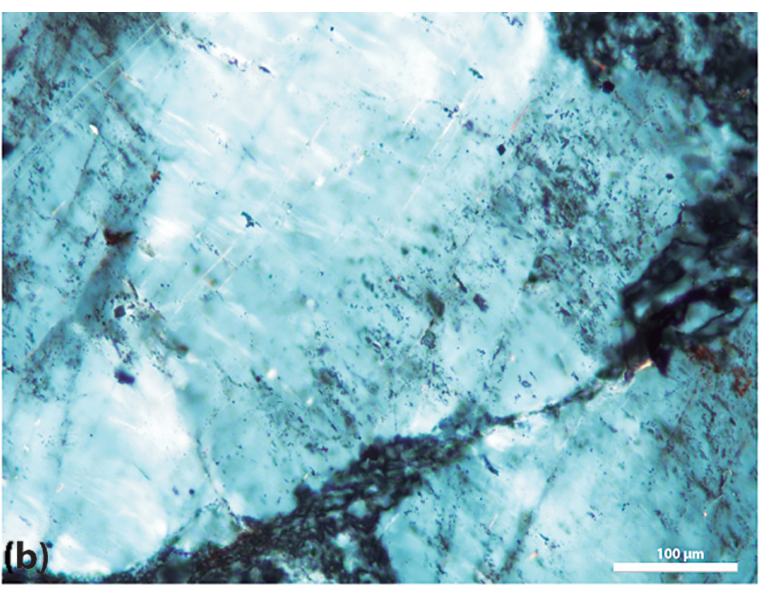

Plagioclase porphyroclasts

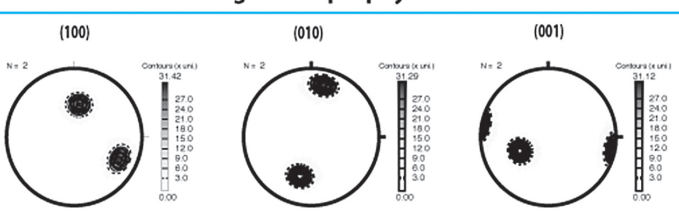

Recrystallized plagioclase
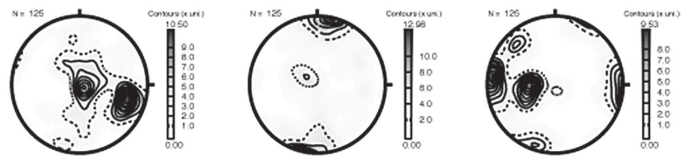

Figure 10. (a) EBSD phase map of an intracrystalline fracture in feldspar porphyroclast (red is quartz; blue is plagioclase; yellow is Kfeldspar). Misorientation profiles A-A' and B-B' are shown in Fig. 11. (b) Optical micrograph of a fracture and its filling; (c) pole figures for feldspar as porphyroclasts and as recrystallized grains. See text for discussion.

and recorded deformation conditions evolving from the submagmatic to the post-magmatic state.

We attempted a more quantitative estimate of the $P, T$ conditions using the two-feldspar thermometry (Stormer,
1975; Whitney and Stormer, 1977). However, given the ultrafine grain size of the recrystallized feldspar and the analytical limitations outlined in Sects. 3.6 and 4.2, this approach did not yield meaningful results. 

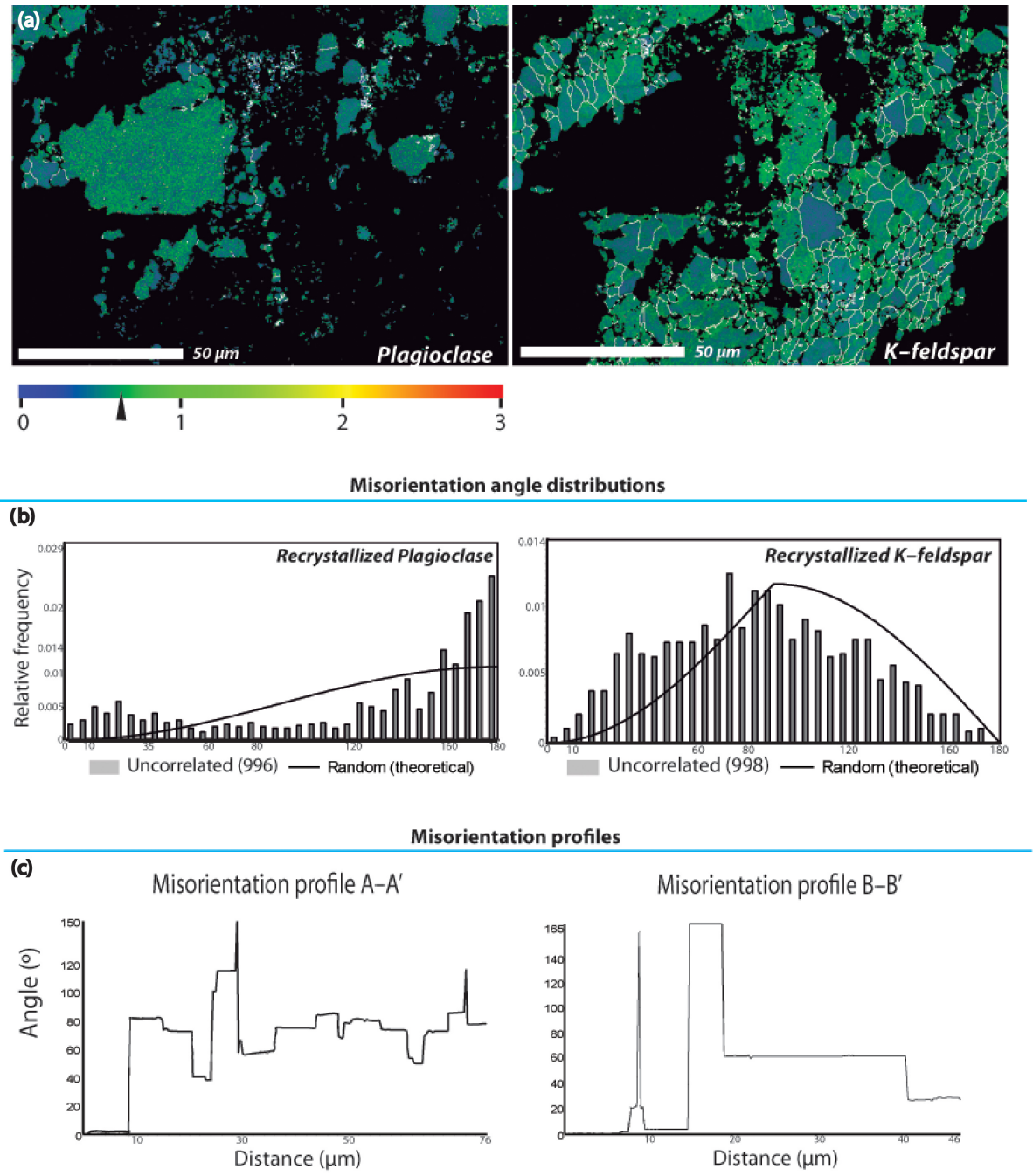

Misorientation profile B-B'

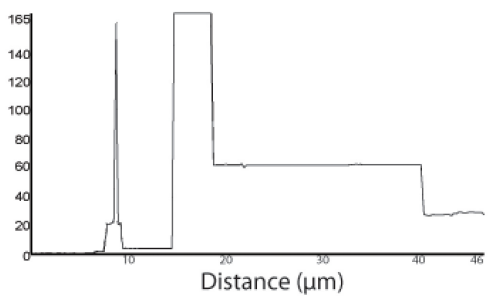

Figure 11. (a) Local misorientation maps of plagioclase and K-feldspar. The maps show the degree of misorientation of each pixel with respect to the neighbouring pixels in a radius of $3 \times 3$ pixels. A threshold of $3^{\circ}$ was used, so that the maps only image the locations of misorientations that are less than $3^{\circ}$. The colour scale shows the degree of misorientation on a scale of 0 to $3^{\circ}$, and the arrow indicates the average misorientation. Low-angle boundaries $>3^{\circ}$ are outlined in white. (b) Misorientation angle distribution of fine-grained plagioclase and K-feldspars (porphyroclasts larger than $15 \mu \mathrm{m}$ are not considered). (c) Misorientation profiles for fine-grained K-feldspar (profile A-A' in Fig. 10) and plagioclase (profile B-B' in Fig. 10) grains. See text for discussion.

Granitoids deforming at similar $T$ to those estimated for sample PE19 frequently show the products of fluid-assisted replacement reactions in feldspars (Menegon et al., 2006; Goncalves et al., 2012; Rosenbaum et al., 2012). There is no evidence for hydration reactions in our sample and feldspars are never replaced by mica-rich aggregates. Thus, reaction weakening cannot account for strain localization in the PE19 shear zone.

This does not necessarily indicate that deformation occurred under dry conditions. The lack of hydration reactions in feldspar can be explained assuming that (1) deformation occurred at $P$ and $T$ conditions at which feldspar was stable both as porphyroclasts and as recrystallized grains or (2) aqueous fluid was present only in amounts sufficiently low to promote dissolution and precipitation processes and diffusivity at grain boundaries but not to trigger hydration reactions in feldspar (e.g. Fukuda et al., 2012).

\subsection{Brittle grain-size reduction of feldspar porphyroclasts and intracrystalline recrystallization}

Feldspar porphyroclasts deformed mainly via microfracturing, resulting in the dismembering of large grains into smaller fragments of heterogeneous grain size (Figs. 4-6). No evidence for internal crystalline plasticity is observed in porphyroclasts, which suggests that at the deformation conditions during mylonitization $\left(\sim 500-550^{\circ} \mathrm{C}\right)$, feldspars acted 

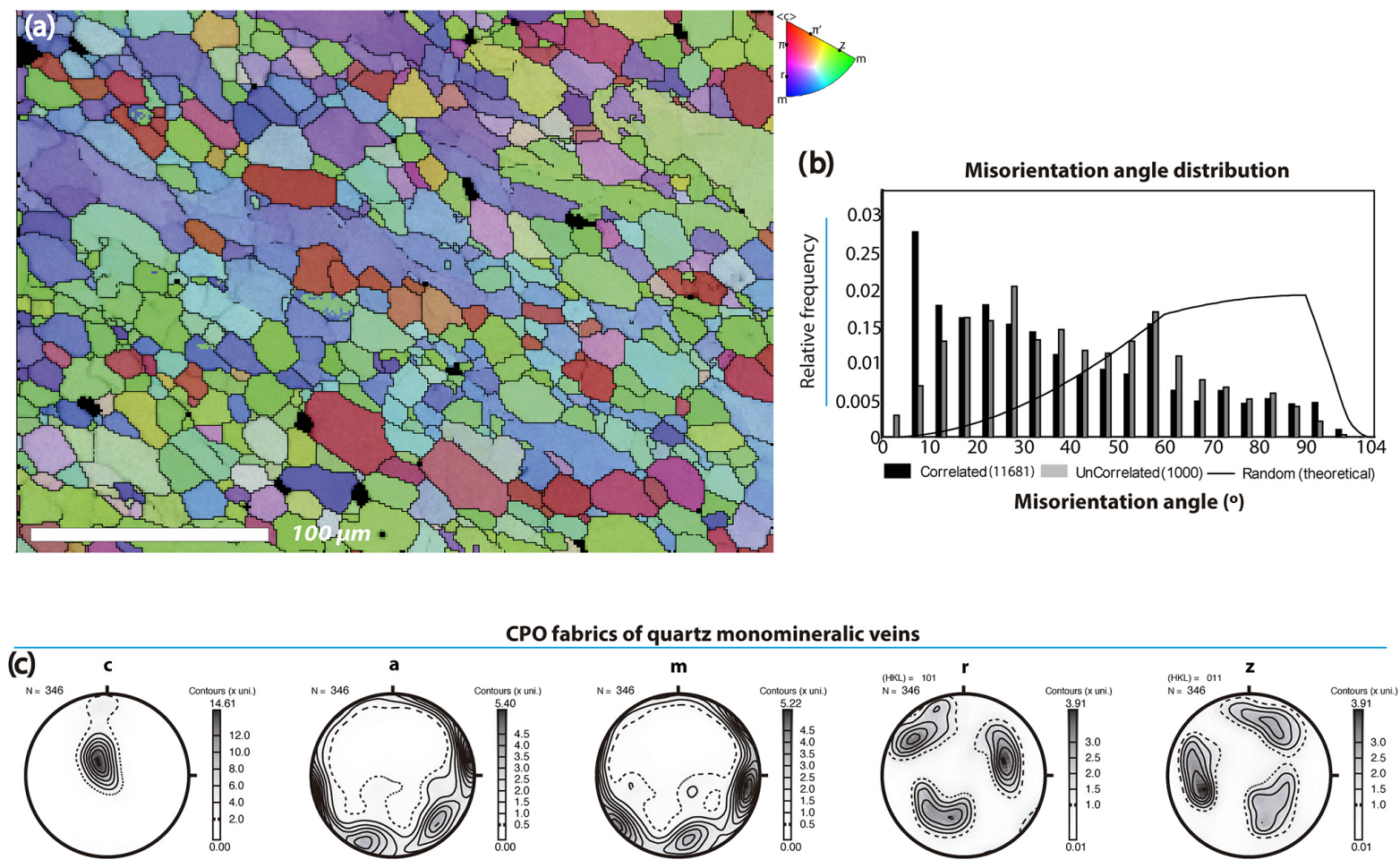

Figure 12. (a) EBSD inverse pole figure map with respect to the normal of the $S$ foliation of a quartz monomineralic vein. (b) Misorientation angle distribution of quartz in the vein. (c) Pole figures of the crystallographic orientation of quartz grains included in (a).

as rigid objects deforming mainly via brittle processes. Although the onset of intracrystalline plasticity in feldspars should occur at $T$ of $400-4500^{\circ} \mathrm{C}$ (Fitz Gerald and Stünitz, 1993; Passchier and Trouw, 2005) there is no clear evidence for crystal-plastic deformation in feldspar porphyroclasts in the studied mylonitic granitoid. Scarce evidence of intracrystalline plasticity in feldspars deforming at $T>450^{\circ} \mathrm{C}$ is not uncommon (e.g. Menegon et al., 2013, and references therein) and should call into question the use of this value as the minimum $T$ required for crystal-plastic deformation of feldspars.

The behaviour of feldspar as a load-bearing framework that accommodates brittle strain while quartz layers undergo solid-state dislocation creep has been previously documented in experimental studies of quartz-feldspar aggregates and is expected to be typical of low greenschist facies conditions at the onset of crystal plasticity in quartz (e.g. Tullis, 2002, and references therein). At amphibolite facies conditions similar to those estimated for the EPSZ, grain-size reduction of feldspars is typically associated with mineral reactions and compositional changes (Wintsch and Yi, 2002; Menegon et al., 2006; Kilian et al., 2011; Fukuda and Okudaira, 2013).

In the mylonitic granitoid studied here, however, no major chemical changes are observed; there is no evidence for feldspar-to-mica reactions, myrmekites are very rare and there is no significant and systematic compositional difference between porphyroclasts and the fine-grained recrystal- lized grains. Furthermore, porphyroclasts show no intracrystalline deformation features and deform mainly via fracturing.

These characteristics suggest that, at the onset of mylonitic deformation in the Pernambuco shear zone, strain was partitioned into solid-state creep in quartz and brittle fracturing in feldspars, causing the segregation of quartz in monomineralic layers and the progressive fragmentation of feldspar porphyroclasts. This process is responsible for the initial grainsize reduction of feldspars to fine-grained aggregates filling the intracrystalline fractures (Figs. 4, 6).

In spite of the lack of clear recovery features in the feldspars porphyroclasts, the crystallographic orientation of the new grains filling the fractures overlaps with the one of the parent grain, particularly for the poles to the (001) planes (Fig. 10). The presence of a CPO in the new grains that resembles that of the porphyroclasts and the lack of substructures in the fine grains suggest that the mixture filling intracrystalline fractures results from epitaxial-oriented growth of feldspar fragments generated during the fracturing process along the fracture walls. Grain rotation within the porphyroclast walls was limited, and grain growth was controlled by dilatant spaces generated during fracturing. Similar oriented growth processes have been documented by Berhmann and Mainprice (1987) in two-feldspar tails around porphyroclasts. Epitaxial growth of K-feldspar in fractures has also been previously described in Menegon et al. (2008a). The 

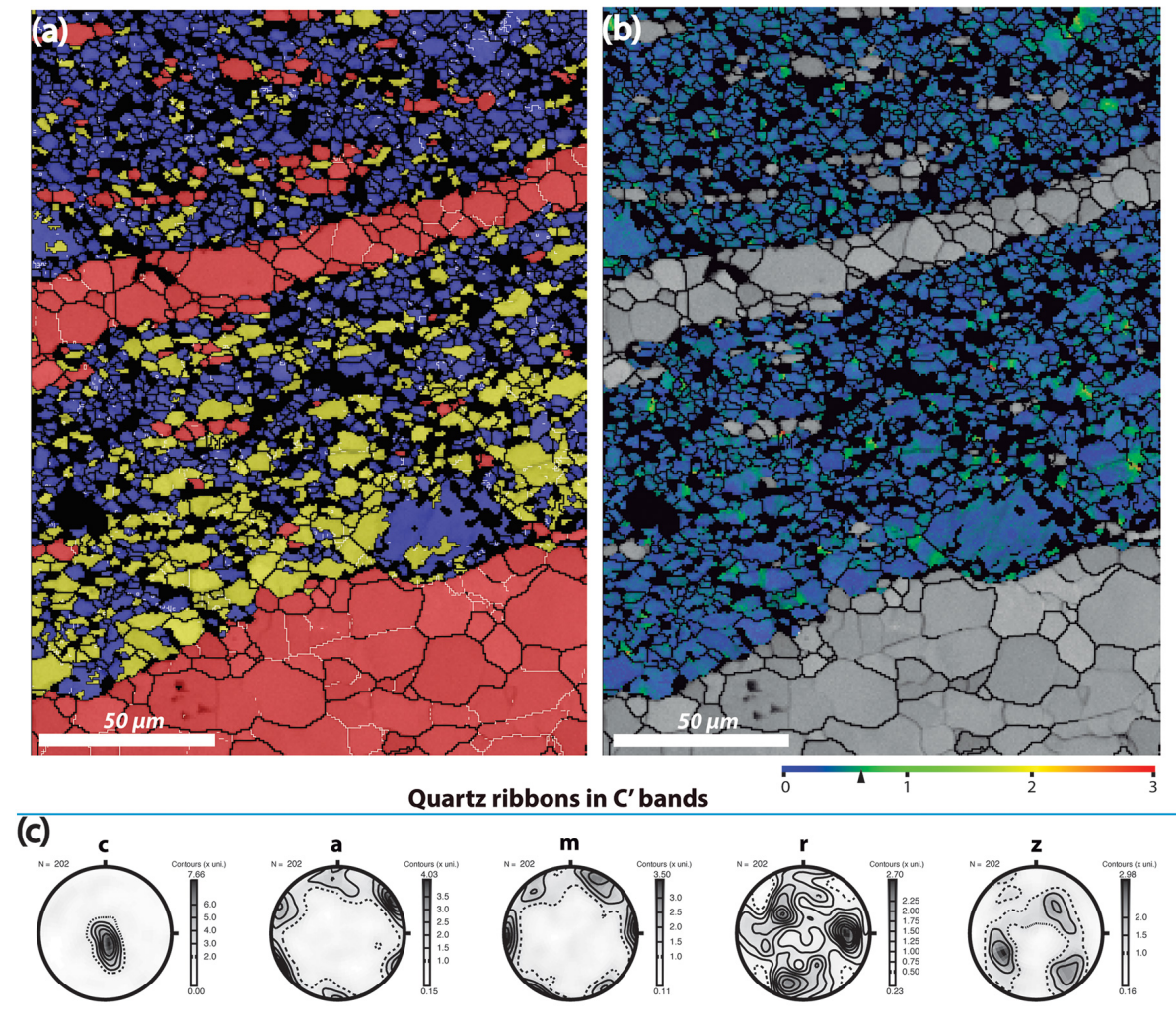

Dispersed quartz in $C^{\prime}$ bands
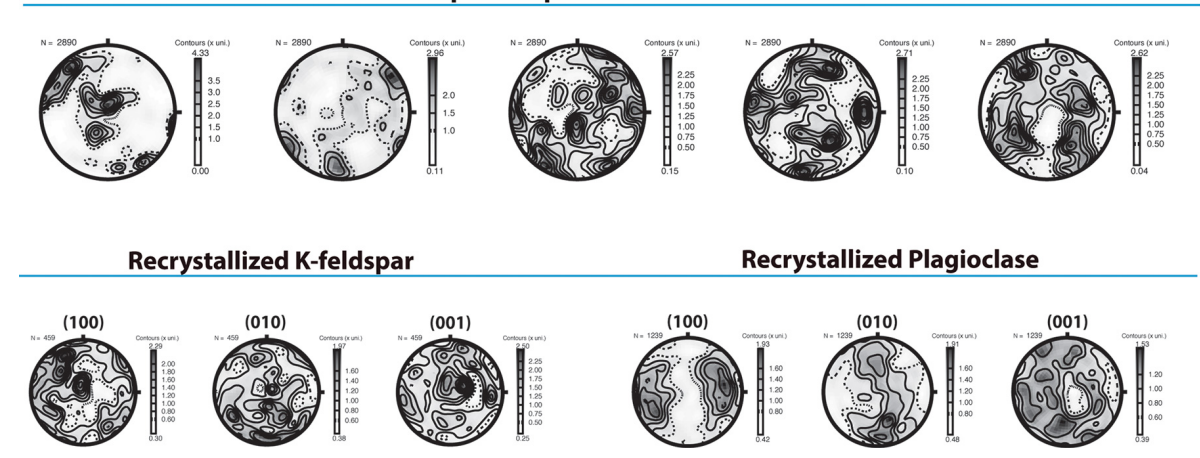

Figure 13. (a) EBSD phase map of a contact between quartz monomineralic veins (red in the bottom of the image) and a feldspathic C' band; red is quartz, blue is plagioclase, yellow is K-feldspar. A thin monomineralic quartz ribbon embedded in the feldspathic matrix is also included in the map. (b) Local misorientation map of the fine-grained feldspathic matrix; colour bar as in Fig. 11. (c) Pole figures of the crystallographic orientation of K-feldspar, plagioclase and quartz (monophasic ribbon and scattered quartz in the matrix are plotted separately). See text for discussion.

marked host control derives from the combined effect of (1) the epitaxial growth of the new grains and (2) the very limited offset accommodated along the intracrystalline fractures, so that grain rotation is virtually negligible (e.g. Trepmann et al., 2007).

With ongoing fracturing in feldspar porphyroclasts, intracrystalline cracks crosscut the large grains and were filled by K-feldspar fragments and fine-grained plagioclase aggregates $\left(\mathrm{Ab}_{91}\right)$. The chemical composition of the fragments is similar to the host porphyroclast, suggesting that there were no significant chemical changes during fracturing and growth of new grains. Due to the similar chemical composition between the porphyroclasts and recrystallized grains in fractures, we speculate that intracrystalline recrystallization was driven by the reduction of surface and strain energy and not by compositional disequilibrium (e.g. Stünitz, 1998; Menegon et al., 2013). However, our limited data set does not allow to draw definitive conclusions on the possible role of chemical disequilibrium. 
Misorientation angle distributions
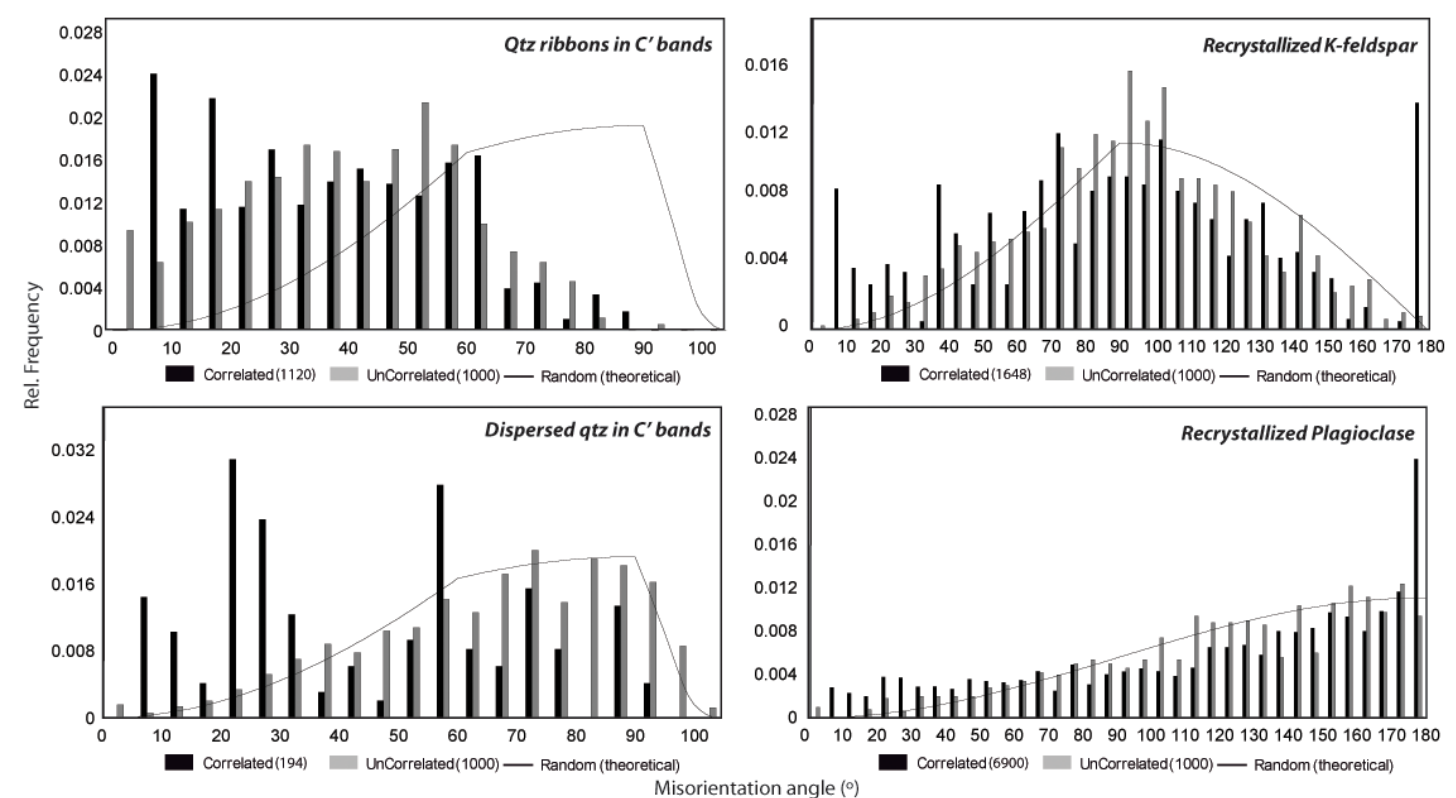

Figure 14. Misorientation angle distributions for the phases within the C' band shown in Fig. 13. See text for discussion.

\subsection{Monomineralic quartz ribbons in ultrafine-grained C' shear bands}

The microstructure and CPO fabrics of the quartz ribbons are similar to that in the monomineralic veins, suggesting that they also deformed via dislocation creep. The $c$ axis CPOs in the ribbon and in the vein are the same and are consistent with the dominant activity of prism $\langle a\rangle$ and rhomb $<a>$ slip systems.

When in contact with fractured and boudinaged feldspar porphyroclasts, the quartz vein typically fills gaps and is squeezed within fractures and boudin necks (Figs. 5a, 6a). This suggests that the veins are locally dismembered and incorporated in the ultrafine-grained matrix as ribbons and continue to deform via dislocation creep. The grain size in the ribbons is smaller than in the monomineralic veins $(5 \mu \mathrm{m}$ vs. $14 \mu \mathrm{m}$ respectively; Fig. 8), suggesting that the ribbons underwent further recrystallization in the matrix, possibly at faster creep rates than in the monophase quartz vein. A progressive reduction of recrystallized grain size of quartz in monophase aggregates deforming by dislocation creep has been described by Casini and Funedda (2014) and has been attributed to enhanced creep rates in layers deforming by pressure solution.

\subsection{Deformation mechanisms in the ultrafine-grained polyphase matrix in C' shear bands}

$\mathrm{K}$-feldspar in the fine-grained matrix shows a very weak $\mathrm{CPO}$ that is not interpretable in terms of activity of intracrys- talline slip systems. The average internal misorientation of $\mathrm{K}$-feldspar grains is of the order of $1^{\circ}$, which suggests that the recrystallized grains are virtually strain free and do not contain low-angle boundaries. These observations are consistent with diffusion creep and grain boundary sliding as the dominant deformation mechanisms in recrystallized Kfeldspar.

Plagioclase grains have a weak CPO (maximum $=1.93$ multiples of the uniform distribution) with the poles to the (100) planes close to $X$ and poles to (010) planes distributed along a girdle in the $Y Z$ plane (Fig. 13). The (100) maximum is parallel to the trace of the C' shear band. Even though the CPO is potentially consistent with dislocation creep on the dominant $(010)<100>$ slip system, our preferred interpretation is that it results from a combination of oriented growth and rigid body rotation during diffusionaccommodated grain boundary sliding. The main arguments for this interpretation are the following: (1) the parent plagioclase porphyroclast grains do not show clear evidence for dislocation creep (see also the large feldspar fragments dispersed in the matrix in Fig. 11); (2) the internal misorientation of the recrystallized plagioclase is very low and there is no evidence for substructures; (3) anisotropic diffusivity and oriented growth in feldspars during diffusion creep accompanied by rigid body rotation are common (e.g. Tullis et al., 1996) and it has been suggested that this can produce a CPO (Heidelbach et al., 2000; Menegon et al., 2008a; Fukuda et al., 2012; Negrini et al., 2014).

In case of anisotropic diffusivity, the resulting CPO is expected to show the crystallographic axis with the fastest dif- 
Wet Anorthite (Rybacki \& Dresen 2000)
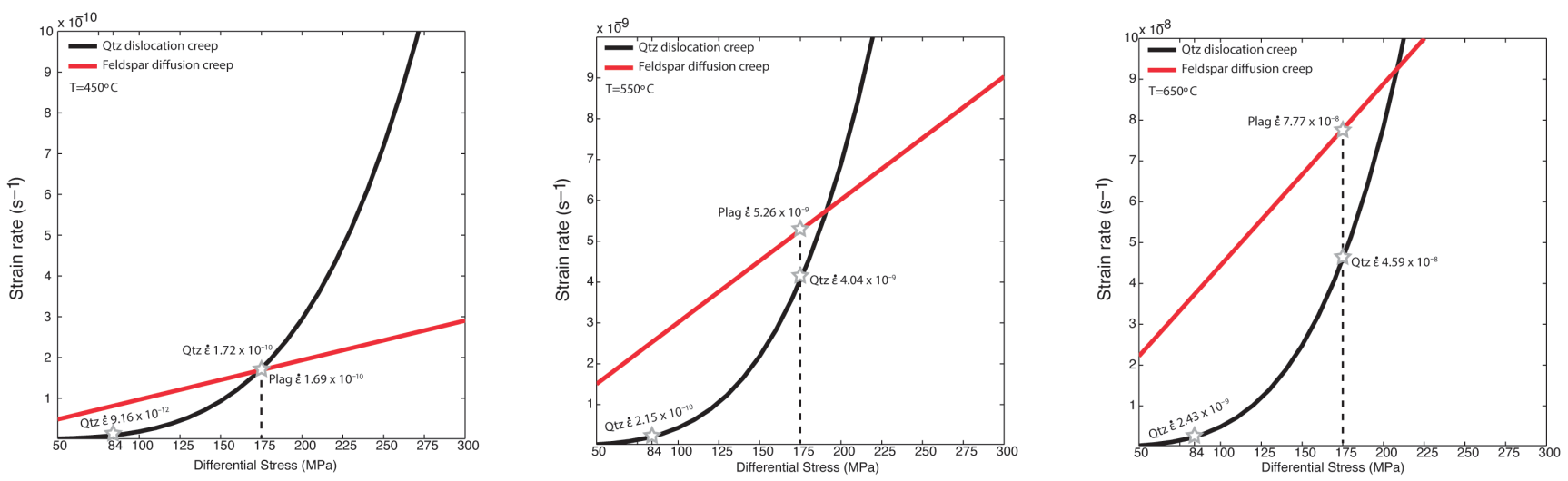

Wet Albite (Offerhaus et al 2001)
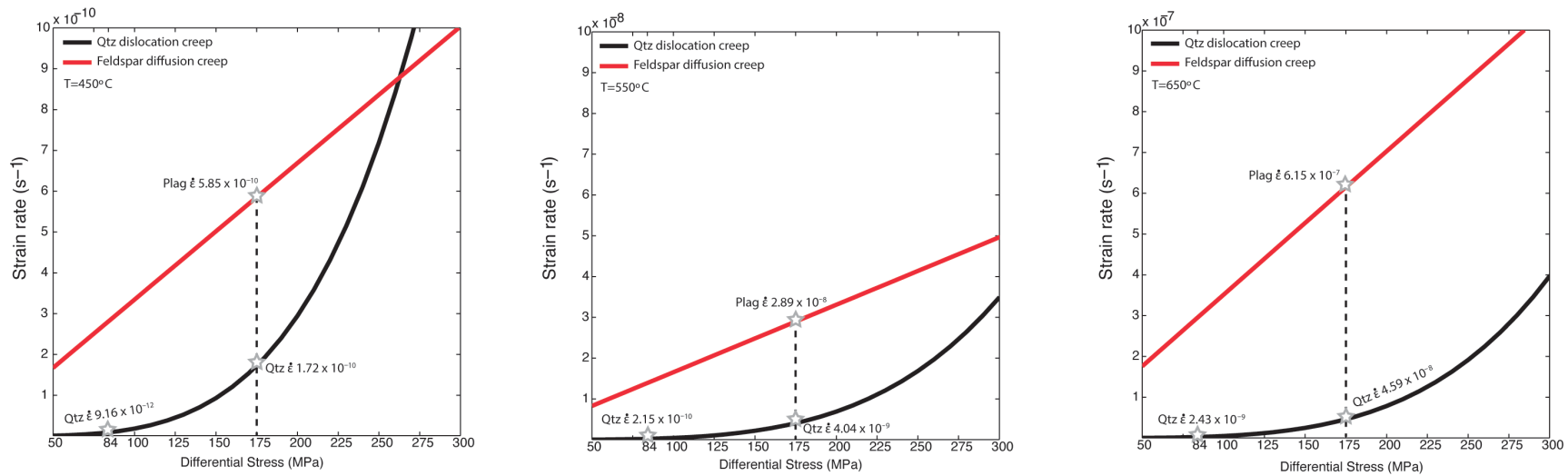

Figure 15. Plots of strain rate vs. differential stress for wet anorthite and wet albite aggregates deforming by diffusion creep and for quartz deforming by dislocation creep. See text for discussion.

fusivity aligned with the instantaneous stretching axis (Bons and den Brok, 2000). The plagioclase CPO in sample PE19 can be interpreted as the result of a fast growth rate parallel to the $\langle 100\rangle$ direction, which has been already reported as a fast growth direction in feldspars (Menegon et al., 2008a; Fukuda et al., 2012; Negrini et al., 2014).

The microstructure of the fine-grained feldspathic matrix, especially the curved/undulose boundaries of K-feldspar grains (Fig. 6b), lends further support to our interpretation. Curved plagioclase-feldspar phase boundaries have typically been interpreted as the result of phase boundary migration and diffusion-accommodated grain boundary sliding (Kilian et al., 2011; Menegon et al., 2013).

The occurrence of isolated quartz grains dispersed in the feldspathic matrix is consistent with precipitation in cavities generated during viscous grain boundary sliding (Fusseis et al., 2009; Menegon et al., 2015; Spruzeniece and Piazolo, 2015). Most of the feldspar grain boundaries appear pitted in the BSE images (Figs. 6,7), and this could indicate the presence of a thin film of fluid along grain boundaries that facilitated diffusion creep and grain boundary sliding in the ultrafine-grained aggregate. The occurrence of isolated quartz grains away from the monophase quartz ribbons is difficult to interpret without invoking creep cavitation. Such isolated quartz grains are free of internal substructures and the $c$ axis $\mathrm{CPO}$ shows maxima near $Y$ and near the instantaneous stretching axis for a sinistral sense of shear. This latter CPO pattern has been observed in fine-grained quartz deforming by diffusion creep (Hippertt, 1994; Kilian et al., 2011) and has been interpreted as the evidence of faster growth rate of quartz grains along the $c$ axis during precipitation in cavities. However, the preservation of a $Y \max$ (similar to the $\mathrm{CPO}$ of the ribbon) might suggest that the ribbons were progressively disintegrated by dissolution and precipitation processes and that some isolated quartz grains represent detached portions of the original ribbon. The close proximity of some of the scattered grains to ribbons and monomineralic veins suggests that they were former parts of the coarse-grained quartz aggregates and were subsequently dismembered and assimilated in the matrix during shear deformation. 


\subsection{Strain localization in the ultrafine-grained polyphase matrix}

Bands of ultrafine-grained polyphase material form an anastomosing pattern wrapping the feldspars porphyroclasts and take up most of the deformation in sample PE19. These bands can be treated as rheologically two-phase materials consisting in a polyphase ultrafine-grained aggregate deforming by diffusion creep and in monophase quartz ribbons deforming by dislocation creep (e.g. Behrmann and Mainprice, 1987; Fliervoet et al., 1997; Kilian et al., 2011; Platt, 2015). Understanding the rheology of such two-phase aggregates is of primary importance, as strain localization in shear zones typically occurs along ultrafine-grained polyphase ultramylonitic bands containing monophase ribbon grains (Platt, 2015).

Platt (2015) recently discussed the rheology of two-phase aggregates and considered the role of grain-size reduction and phase mixing on strain localization in polyphase mixtures. The results of Platt (2015) indicate that polyphase mixtures in ultramylonites formed by dynamic recrystallization and subsequent deformed by diffusion creep. The rheology of the aggregate would therefore be controlled by the strength of the fine-grained aggregate that is capable of deforming at faster strain rates than the monophase layers.

In order to assess the rheological behaviour of the polyphase aggregate in C' shear bands we applied experimentally derived flow laws for quartz deforming via dislocation creep and feldspar deforming via diffusion creep. The rheology of quartz deforming by dislocation creep is generally described in terms of a power law equation:

$\dot{\varepsilon}=A f_{\mathrm{H}_{2} \mathrm{O}}^{m} e^{(-Q / \mathrm{RT})} \sigma^{n}$,

with the stress exponent $n=4$ for the flow law used in this study (Hirth et al., 2001; Table 2). Hirth et al. (2001) considered a linear dependence of strain rate on the water fugacity $(m=1)$. Water fugacity was calculated from the water fugacity coefficients reported by Tödheide (1972) at $P=0.5 \mathrm{GPa}$ and $T=450^{\circ} \mathrm{C}, 550$ and $650{ }^{\circ} \mathrm{C}$.

The rheology of feldspar deforming by diffusion creep can be described in terms of a linear equation:

$\dot{\varepsilon}=A \sigma^{n} d^{-m} \exp \left(-\frac{Q}{\mathrm{RT}}\right)$,

using the flow law parameters shown in Table 2. We used the diffusion creep flow laws of wet anorthite (Rybacki and Dresen, 2000), which was calibrated for grain boundary diffusion-controlled creep (Rybacki and Dresen, 2004). In order to test the potential influence of compositional variations of feldspars on the diffusion creep deformation we also used the diffusion creep flow law for wet albite aggregates (Offerhaus et al., 2001). However, it should be noted that the diffusion creep flow law for anorthite is experimentally better constrained than the one for albite (G. Dresen, personal communication, 2016). Furthermore, the effect of compositional variations on the diffusion creep behaviour of feldspars appears to be negligible compared to the effect of water (Rybacki and Dresen, 2004).

We assumed uniform stress conditions during viscous deformation across the thin $\mathrm{C}^{\prime}$ shear bands, as suggested by the formation of shear-parallel quartz ribbons with no evidence for boudinage, pinch and swell or buckling instabilities (Mehl and Hirth, 2008; Montesi, 2013) and by the constant thickness of the shear band along its whole length. The assumption of uniform stress conditions is reasonable since we do not observe clear evidence of cyclic oscillation of stress in the microstructure. For example, recrystallized quartz grains in the vein and in the ribbon are never overprinted by fine bulges that would possibly indicate an increase in flow stress. We evaluated the differential stress in the shear bands by applying the recrystallized grain-size piezometer for quartz calibrated by Stipp and Tullis (2003) to the monomineralic quartz ribbons. The calculations yielded differential stress values of $175 \mathrm{MPa}$ (for a recrystallized grain size of $\sim 5 \mu \mathrm{m}$, see Fig. 8). We considered this differential stress as representative of the flow stress experienced by the whole shear band during viscous creep, and we used it to derive the strain rate of quartz deforming by dislocation creep and of feldspar deforming by diffusion creep. The aim of our rheological modelling is to compare the strain rates in the shear band and in the monomineralic quartz vein. An average grain size of $\sim 14 \mu \mathrm{m}$ in the recrystallized quartz vein (Fig. 8) yields a differential stress of $84 \mathrm{MPa}$.

Figure 15 summarizes the results of our calculations over a broad $T$ range representative of mid-crustal conditions (450 $650^{\circ} \mathrm{C}$ ). For wet anorthite flow law parameters, the $T$ range of mylonitic deformation in the EPSZ $\left(450-650^{\circ} \mathrm{C}\right)$ yields similar strain rates for quartz deforming by dislocation creep and feldspar deforming by diffusion creep in the shear band (upper part of Fig. 15). These strain rates are always 1 order of magnitude faster than those estimated for dislocation creep deformation of quartz in the monomineralic veins.

At the estimated $T$ conditions for the development of the mylonitic granitoid of our study $\left(\sim 550^{\circ} \mathrm{C}\right)$, diffusion creep in feldspar occurs at comparable strain rates as dislocation creep in quartz $\left(5.2 \times 10^{-9}\right.$ and $4.04 \times 10^{-9} \mathrm{~s}^{-1}$ respectively). However, dislocation creep in quartz monomineralic veins occurs at 1 order of magnitude slower than in the feldspathic shear bands $\left(2.15 \times 10^{-10} \mathrm{~s}^{-1}\right)$.

Using the diffusion creep flow for wet albite aggregates, the differences are even more pronounced (Fig. 15). Albite is remarkably weaker than quartz ribbons in the shear bands along the $T$ range of mylonitization in the EPSZ $\left(450-650^{\circ} \mathrm{C}\right)$. At the estimated $T$ conditions of this study $\left(550^{\circ} \mathrm{C}\right)$, diffusion creep in the feldspathic matrix is 1 to 2 orders of magnitude faster $\left(2.89 \times 10^{-8} \mathrm{~s}^{-1}\right)$ than in the quartz ribbons $\left(4.04 \times 10^{-9} \mathrm{~s}^{-1}\right)$. Furthermore, both strain rates in the polyphase shear bands are 1 order of magnitude faster than dislocation creep in quartz monomineralic veins 
Table 2. Flow law parameters for quartz and feldspar used in this study.

\begin{tabular}{llllll}
\hline Flow law & $A\left(\mathrm{MPa}^{-1} \mathrm{~s}^{-1}\right)$ & $m$ & $Q\left(\mathrm{~kJ} \mathrm{~mol}^{-1}\right)$ & $n$ & \\
\hline Hirth et al. (2001) & $6.30957 \times 10^{-12}$ & 1 & 135 & 4 & \\
& $\log A\left(\mathrm{MPa}^{-n} \mu \mathrm{m}^{m} \mathrm{~s}^{-1}\right)$ & & & & $\mathrm{H}_{2} \mathrm{O} \mathrm{wt} \%$ \\
Wet An - Rybacki and Dresen (2000) & $1.7 \pm 0.2$ & 3 & $170 \pm 6$ & $1.0 \pm 0.1$ & 0.07 \\
Wet Ab - Offerhaus et al. (2001) & $3.9 \pm 1.1$ & 3 & $193 \pm 25$ & 1 & 0.2 \\
\hline
\end{tabular}

$\left(2.15 \times 10^{-10} \mathrm{~s}^{-1}\right)$. However, as already pointed out, this result has to be taken with caution given the uncertainties in the mechanical data of albite.

We are aware that caution should be taken in the extrapolation of experimental flow laws to nature over several orders of magnitude in strain rate. Furthermore, major uncertainties exist in the piezometric relationship and in the flow law parameters. Being aware of these limitations, our calculations provide a qualitative assessment of the potential strain rate increase in ultrafine-grained feldspathic layers deforming by diffusion creep, which in turn represents a viable mechanical explanation for strain localization in these polyphase layers. These results further suggest that deformation is accommodated in the fine-grained matrix, which localizes strain and deforms at faster creep rates via diffusion creep while dislocation creep in the quartz veins proceeds at slower rates than in the fine-grained polyphase aggregate. It is worth noting that results from dry anorthite aggregates yield unrealistic slow strain rates at $550^{\circ} \mathrm{C}\left(1.86 \times 10^{-17} \mathrm{~s}^{-1}\right)$, which would be difficult to reconcile with the observed strain localization within the shear bands.

In summary, we conclude that in the mylonitic granitoid studied here, initial deformation of quartz-feldspathic aggregates occurred by a combination of fracturing in feldspars and crystal plasticity in quartz. Quartz accommodates solidstate creep while feldspars act as rigid objects undergoing progressive grain-size reduction via fracturing. With ongoing deformation, feldspar is progressively reduced to a finegrained matrix of average grain size of about $3 \mu \mathrm{m}$ that deforms by dominant grain-size sensitive creep. Such finegrained polyphase matrix accommodates most of the strain, thus controlling the rheology of the aggregate (e.g. Platt, 2015).

Overall, our conclusions are in agreement with those recently showed by Platt (2015) and extend them, because (1) there is evidence for grain-size reduction via brittle processes being a viable mechanism to promote viscous flow at amphibolite facies conditions and (2) deformation of polyphase aggregates occurs at 1 order of magnitude faster than in monophase aggregates, leading to strain localization in the aggregate deriving from the initially stronger phase i.e. feldspar.

The fact that there is no significant breakdown of feldspar into reaction products constitutes additional evidence for the importance of brittle processes in promoting grain-size re- duction and subsequent strain localization at mid-crustal conditions. We speculate that two potential reasons for the dominant brittle deformation of feldspars may be (1) fast strain rates, potentially associated with the downward propagation of seismic ruptures along the Pernambuco Shear Zone; and (2) an extremely low amount of intracrystalline water content in feldspars, which was insufficient to activate crystal plasticity (e.g. Bürgmann and Dresen, 2008). Quantitative measurements of intracrystalline water contents in feldspar porphyroclasts and along grain boundaries are required to draw more accurate conclusions.

\section{Conclusions}

In the mylonitic granitoid of the Eastern Pernambuco Shear Zone, NE Brazil, grain-size reduction of feldspars was attained via fracturing at $P, T$ conditions typical of the middle crust ( $\left.\sim 500-550^{\circ} \mathrm{C}, 5 \mathrm{kbar}\right)$. Metamorphic reactions did not play any role in the weakening mechanisms associated with strain localization in the shear zone. Microstructures, EBSD analysis, chemical data and extrapolation of laboratory-derived flow laws allow us to draw the following considerations:

- Brittle grain-size reduction of feldspars resulted in the formation of ultrafine-grained polyphase feldspathic bands and triggered a switch from fracturing to grainsize sensitive creep.

- Monophase polycrystalline quartz ribbons deformed by dislocation creep throughout the entire deformation history. However, the grain size of recrystallized quartz decreases when moving from thick (up to $0.5 \mathrm{~cm}$ ) monomineralic veins to thin $(<20 \mu \mathrm{m})$ ribbons embedded in the polyphase feldspathic matrix. The decrease in grain size is attributed to an increase in strain rate and strain localization in the polyphase bands.

- Assuming that thin shear bands deformed at uniform stress conditions, a qualitative assessment of the rheology of localized shear bands indicates that strain rate in the feldspar-rich aggregate deforming by diffusion creep was 1 order of magnitude faster than in monophase quartz veins deforming by dislocation creep. 
In summary, our study highlights the importance of brittle grain-size reduction and subsequent diffusion creep deformation for strain localization in mid-crustal rocks. Rheological models are likely to yield an incomplete view of the mechanical evolution of lithospheric shear zones if this interplay between brittle and viscous mechanisms in space and time is neglected.

Acknowledgements. Gustavo Viegas and Carlos Archanjo acknowledge FAPESP financial support (grants 2013/11866-9 and 2014/01114-2). Luca Menegon acknowledges the financial support from a FP7 Marie Curie Career Integration Grant (grant agreement PCIG13-GA-2013-618289). We gratefully acknowledge the constructive reviews of two anonymous referees and the editorial handling of Giorgio Pennacchioni. The staff at Plymouth University Electron Microscopy Centre is warmly thanked for excellent support during SEM-based analyses. Giulia Degli Alessandrini is thanked for helping with the figures. This paper benefited from many fruitful discussions with Benoit Ildefonse, Alain Vauchez, Roberto Agrusta, Dani Schmid, Philippe Goncalves, Sina Marti, Neil Mancktelow, Luiz Morales and Giorgio Pennacchioni.

Edited by: G. Pennacchioni

\section{References}

Archanjo, C. J., Bouchez, J. L., Corsini, M., and Vauchez, A.: The Pombal granite pluton: magnetic fabric, emplacement and relationships with the Brasiliano strike-slip setting of NE Brazil (Paraiba State), J. Struct. Geol., 16, 323-335, 1994.

Behrmann, J. H. and Mainprice, D.: Deformation mechanisms in a high-temperature quartz-feldspar mylonite: evidence for superplastic flow in the lower continental crust, Tectonophysics, 140, 297-305, 1987.

Bercovici, D. and Ricard, Y.: Mechanisms for the generation of plate tectonics by two-phase grain damage and pinning, Phys. Earth Planet. In., 202-203, 27-55, 2012.

Bons, P. and den Brok, B.: Crystallographic preferred orientation development by dissolution precipitation creep, J. Struct. Geol., 22, 1713-1722, 2000.

Bürgmann, R. and Dresen, G.: Rheology of the lower crust and upper mantle: evidence from rock mechanics, geodesy, and field observations, Annu. Rev. Earth Pl. Sc., 36, 531-567, 2008.

Casini, L. and Funedda, A.: Potential of pressure solution for strain localization in the Baccu Locci shear zone (Sardinia, Italy), J. Struct. Geol., 66, 188-204, 2014.

Czaplinska, D., Piazolo, S., and Zibra, I.: The influence of phase and grain size distribution on the dynamics of strain localization in polymineralic rocks, J. Struct. Geol., 72, 15-32, 2015.

Davison, I., McCarthy, M., Powell, D., Torres, H. F., and Santos, C. A.: Laminar flow in shear zones: the Pernambuco shear zone, NE Brazil, J. Struct. Geol., 17, 149-161, 1995.

Fitz Gerald, J. D. and Stünitz, H.: Deformation of granitoids at low-metamorphic grade. I: Reactions and grain size reduction, Tectonophysics, 221, 269-297, 1993.

Fliervoet, T., White, S., and Drury, M.: Evidence for dominant grain-boundary sliding deformation in greenschist and amphibolite-grade polymineralic ultramylonites from the Redbank Deformed Zone, Central Australia, J. Struct. Geol., 19, 1495-1520, 1997.

Fukuda, J. and Okudaira, T.: Grain-size-sensitive creep of plagioclase accompanied by solution precipitation and mass transfer under mid-crustal conditions, J. Struct. Geol., 51, 61-73, doi:10.1016/j.jsg.2013.03.006, 2013.

Fukuda, J., Okudaira, T., Satsukawa, and T., Michibayashi: Solution-precipitaton of K-feldspar in deformed granitoids and its relationship to the distribution of water, Tectonophysics, 532535, 175-185, 2012.

Fusseis, F., Regenauer-Lieb, K., Liu, J., Hough, R. M., and De Carlo, F.: Creep cavitation can establish a dynamic granular fluid pump in ductile shear zones, Nature, 459, 974-977, 2009.

Goncalves, P., Oliot, E., Marquer, D., and Connolly, J. A. D.: Role of chemical processes on shear zone formation: an example from the Grimsel metagranodiorite (Aar massif, Central Alps), J. Metamorph. Geol., 30, 703-722, 2012.

Gueydan, F., Leroy, Y. M., Jolivet, L., and Agard, P.: Analysis of continental midcrustal strain localization induced by reactionsoftening and microfracturing, J. Geophys. Res., 108, 2064, doi:10.1029/2001JB000611, 2003.

Handy, M. R., Hirth, G., and Bürgmann, R.: Continental fault structure and rheology from the frictional to-viscous transition downward, in: Dahlem Workshop Reports, edited by: Handy, M. R., Hirth, G., and Hovius, N., The MIT Press, Cambridge, USA, 139-181, 2007.

Heidelbach, F., Post, A., and Tullis, J.: Crystallographic preferred orientation in albite samples deformed experimentally by dislocation and solution precipitation creep, J. Struct. Geol., 22, 1649-1661, 2000.

Herwegh, M., Linckens, J., Ebert, A., Berger, A., and Brodhag, S. H.: The role of second phases for controlling microstructural evolution in polymineralic rocks: a review, J. Struct. Geol., 33, 1728-1750, 2011.

Hippertt, J. F.: Microstructures and $c$-axis fabrics indicative of quartz dissolution in sheared quartzites and phyllonites, Tectonophysics, 229, 141-163, doi:10.1016/0040-1951(94)90026-4, 1994,

Hirth, G., Teyssier, C., and Dunlap, J.: An evaluation of quartzite flow laws based on comparisons between experimentally and naturally deformed rocks, Int. J. Earth Sci., 90, 77-87, doi:10.1007/s005310000152, 2001.

Holland, T. and Blundy, J.: Non-ideal interactions in calcic amphiboles and their bearing on amphibole-plagioclase thermometry, Contrib. Mineral. Petr., 116, 433-447, 1994.

Kilian, R., Heilbronner, R., and Stunitz, H.: Quartz grain size reduction in a granitoid rock and the transition from dislocation to diffusion creep, J. Struct. Geol., 33, 1265-1284, 2011.

Ingles, J., Lamouroux, C., Soula, J.-C., Guerrero, N., and Debat, P.: Nucleation of ductile shear zones in a granodiorite under greenschist facies conditions, Néouvielle massif, Pyrenees, France, J. Struct. Geol., 21, 555-575, 1999.

Mancktelow, N. and Pennacchioni, G.: The influence of grain boundary fluids on the microstructure of quartz-feldspar mylonites, J. Struct. Geol., 26, 47-69, 2004.

Mehl, L. and Hirth, G.: Plagioclase preferred orientation in layered mylonites: evaluation of flow laws for the lower crust, J. Geophys. Res., 113, B05202, doi:10.1029/2007JB005075, 2008. 
Menegon, L. and Pennacchioni, G.: Local shear zone pattern and bulk deformation in the Gran Paradiso metagranite (NW Italian Alps), Int. J. Earth Sci., 99, 1805-1825, 2010.

Menegon, L., Pennacchioni, G., and Stunitz, H.: Nucleation and growth of myrmekite during ductile shear deformation in metagranites, J. Metamorph. Geol., 24, 553-568, 2006.

Menegon, L., Pennacchioni, G., and Spiess, R.: Dissolutionprecipitation creep of K-feldspar in mid crustal granite mylonites, J. Struct. Geol., 30, 565-579, 2008a.

Menegon, L., Pennacchioni, G., Heilbronner, R., and Pitarello, L.: Evolution of quartz microstructure and c-axis crystallographic preferred orientation within ductileely deformed granitoids (Arolla unit, Western Alps), J. Struct. Geol., 30, 1332 1347, 2008b.

Menegon, L., Nasipuri, P., Stünitz, H., Behrens, H., and Ravna, E.: Dry and strong quartz during deformation of the lower crust in the presence of melt, J. Geophys. Res., 116, B10410, doi:10.1029/2011JB008371, 2011.

Menegon, L., Stunitz, H., Nasipuri, P., Heilbronner, R., and Svahnberg, H.: Transition from fracturing to viscous flow in granulite facies perthitic feldspar (Lofoten, Norway), J. Struct. Geol., 48, 95-112, 2013.

Menegon, L., Fusseis, F., Stunitz, H., and Xiao, X.: Creep cavitation bands control porosity and fluid flow in lower crustal shear zones, Geology, 43, 227-230, 2015.

Montesi, L.: Fabric development as the key for forming ductile shear zones and enabling plate tectonics, J. Struct. Geol., 50, 254-266, doi:10.1016/j.jsg.2012.12.011, 2013.

Negrini, M., Stunitz, H., Nasipuri, P., Menegon, L., and Morales, L. F. G.: Semibrittle deformation and partial melting of perthitic K-feldspar: an experimental study, J. Geophys. Res., 119, 34783502, 2014.

Neves, S. P.: Constraints from zircon geochronology on the tectonic evolution of the Borborema Province (NE Brazil): widespread intracontinental Neoproterozoic reworking of a Paleoproterozoic accrectionary orogeny, J. S. Am. Earth Sci., 58, 150-164, 2015.

Neves, S. P., Vauchez, A., and Ferraud, G.: Tectono-thermal evolution, magma emplacement and shear zone development in the Caruaru area (Borborema Province, NE Brazil), Precambrian Res., 99, 1-32, 2000.

Offerhaus, L. J., Wirth, R., and Dresen, G.: High temperature creep of polycrystalline albite, in: Deformation mechanisms, Rheology and Tectonics, edited by: de Meer, S., Drury, M. R., de Bresser, J. H. P., and Pennock, G. M., Utrecht Univ., the Netherlands, 124 pp., 2001.

Okudaira, T. and Shigematsu, N.: Estimates of stress and strain rate in mylonites based on the boundary between the fields of grain-size sensitive and insensitive creep, J. Geophys. Res., 117, B03210, doi:10.1029/2011JB008799, 2012.

Oliot, E., Goncalves, P., and Marquer, D.: Role of plagioclase and reaction softening in a metagranite shear zone at mid-crustal conditions (Gotthard Massif, Swiss Central Alps), J. Metamorph. Geol., 28, 849-871, 2010.

Park, Y., Yoo, S.-H., and Ree, J.-H.: Weakening of deforming granitic rocks with layer development in the middle crust, J. Struct. Geol., 28, 919-928, 2006.

Passchier, C. W. and Trouw, R. A. J.: Microtectonics, SpringerVerlag, Heidelberg, 2005.
Pennacchioni, G. and Mancktelow, N. S.: Nucleation and initial growth of a shear zone network within compositionally and structurally heterogeneous granitoids under amphibolite facies conditions, J. Struct. Geol., 29, 1757-1780, doi:10.1016/j.jsg.2007.06.002, 2007.

Pennacchioni, G., Menegon, L., Leiss, B., Nestola, F., and Bromiley, G.: Development of crystallographic preferred orientation and microstructure during plastic deformation of natural coarse grained quartz veins, J. Geophys. Res., 115, B12405, doi:10.1029/2010JB007674, 2010.

Platt, J.: Rheology of two-phase systems: a microphysical and observational approach, J. Struct. Geol., 77, 213-227, 2015.

Ree, J.-H., Kim, H. S., Han, R., and Jung, H.: Grain-size redudction of feldspars by fracturing and neocrystallization in a low-grade granitic mylonite and its rheological effect, Tectonophysics, 407, 227-237, doi:10.1016/j.tecto.2005.07.010, 2005.

Rybacki, E. and Dresen, G.: Dislocation and diffusion creep of synthetic anorthite aggregates, J. Geophys. Res., 105, 26.01726.036, 2000.

Rybacki, E. and Dresen, G.: Deformation mechanism maps for feldspar rocks, Tectonophysics, 382, 173-187, 2004.

Rosenbaum, G., Menegon, L., Glodny, J., Vasconcelos, P., Ring, U., Massironi, M., Thiede, D., and Nasipuri, P.: Dating deformation in the Gran Paradiso massif (NW Italian Alps): implications for the exhumation of high-pressure rocks in a collisional belt Lithos, 144-145, 130-144, 2012.

Schmid, S. and Casey, M.: Complete fabric analysis of some commonly observed quartz c-axis patterns, in: Mineral and Rock Deformationl: Laboratory Studies, edited by: Hobbs, B. and Heard, H., the Paterson volume, Geophysical Monograph, 36, 263-286. 1986.

Spruzeniece, L. and Piazolo, S.: Strain localization in brittle-ductile shear zones: fluid-abundant vs. fluid-limited conditions (an example from Wyangala area, Australia), Solid Earth, 6, 881-901, doi:10.5194/se-6-881-2015, 2015.

Stormer, J.: A practical two-feldspar geothermometer, Am. Mineral., 60, 667-674, 1975.

Stünitz, H.: Syndeformational recrystallization - dynamic or compositionally induced?, Contrib. Mineral. Petr., 131, 219-236, 1998.

Stünitz, H. and Tullis, J.: Weakening and strain localization produced by syn-deformational reaction of plagioclase, Int. J. Earth Sci., 90, 136-148, 2001.

Simpson, C. and Wintsch, R. P.: Evidence for deformation induced K-feldspar replacement by myrmekite, J. Metamorph. Geol., 7, 261-275, 1989.

Stipp, M. and Tullis, J.: The recrystallized grain size piezometer for quartz, Geophys. Res. Lett., 30, 2088, doi:10.1029/2003GL018444, 2003.

Stipp, M., Stunitz, H., Heilbronner, R., and Schmid, S.: The eastern Tonale fault zone: a "natural laboratory" for crystal plastic deformation of quartz over a temperature range from 250 to $700^{\circ} \mathrm{C}$, J. Struct. Geol., 24, 1861-1884, 2002.

Stipp, M., Tullis, J., Scherwath, M., and Behrmann, J.: A new perspective on paleopiezometry: dynamically recrystallized grain size distributions indicate mechanism changes, Geology, 38, 759-762, 2010.

Sullivan, W. A., Boyd, A. S., and Monz, M. E.: Strain localization in homogeneous granite near the brittle-ductile transition: a case 
study of the Kellyland fault zone, Maine, USA, J. Struct. Geol., 56, 70-88, 2013.

Tödheide, K.: Water at high temperatures and pressures, in: Water: A Comprehensive Treatise, edited by: Franks, F., vol. 1, chap. 13, 463-514, Springer, New York, 1972.

Tommasi, A., Vauchez, A., Fernandes, L. A. D., and Porcher, C. C.: Magma-assisted strain localization in an orogen-pararell transcurrent shear zone of southern Brazil, Tectonics, 13, 421-437, 1994.

Trepmann, C., Stockhert, B., Dorner, D., Moghadam, R., Kuster, M., and Roller, K.: Simulating coseismic deformation of quartz in the middle crust and fabric evolution during postseismic stress relaxation - an experimental study, Tectonophysics, 442, 83104, 2007.

Tsurumi, J., Hosonoma, H., and Kanagawa, K.: Strain localization due to a positive feedback of deformation and myrmekiteforming reaction in granite and aplite mylonites along the Hatagawa Shear Zone of NE Japan, J. Struct. Geol., 25, 557-574, 2003.

Tullis, J.: Deformation of granitic rocks; experimental studies and natural examples, in: Plastic deformation of minerals and rocks, Rev. Mineral. Geochem., 51, 51-95, 2002.

Tullis, J., Yund, R., and Farver, J.: Deformation-enhanced fluid distribution in feldspar aggregates and implications for ductile shear zones, Geology, 24, 63-66, 1996.
Vauchez, A. and Egydio-Silva, M.: Termination of a continentalscale strike-slip fault in partially melted crust: the West Pernambuco shear zone, northeast Brazil, Geology, 20, 1007-1010, 1992.

Vauchez, A., Neves, S. P., Caby, R., Corsini, M. E., Egydio Silva, M., Arthaud, M., and Amaro, V. E.: The Borborema shear zone system, NE Brazil, J. S. Am. Earth Sci., 8, 247-266, 1995.

Viegas, G., Archanjo, C. J., and Vauchez, A.: Fabrics of migmatites and the relationships between partial melting and deformatio in high-grade transpressional shear zones: The Espinho Branco anatexite (Borborema Prince, NE Brazil), J. Struct. Geol., 48, 45-56, 2013.

Warren, J. and Hirth, G.: Grain size sensitive deformation mechanisms in naturally deformed peridotites, Earth Planet. Sc. Lett., 248, 438-450. 2006.

Wintsch, R. P. and Yi, K.: Dissolution and replacement creep: a significant deformation mechanism in mid-crustal rocks, J. Struct Geol., 24, 1179-1193, 2002.

Whitney, J. A. and Stormer, J. C.: Two-feldspar geothermometry, geobarometry in mesozonal granitic intrusions: three examples from the Piedmont of Georgia, Contrib. Mineral. Petr., 63, 5164, 1977.

Zibra, I., Kruhl, J., Montanini, A., and Tribuzio, R.: Shearing of magma along a high-grade shear zone: evolution of microstructures during the transition from magmatic to solid-state flow, $\mathrm{J}$ Struct. Geol., 37, 150-160, 2012. 